\title{
Liaison Activities with the Institute of Physical Chemistry, Russian Academy of Sciences: FY 1996
}

Calvin H. Delegard

Date Published

September 1996

Prepared for the U.S. Department of Energy

Assistant Secretary for Environmental Management

\footnotetext{
(2) Westinghouse P.O. Box 1970

Hanford Company Richland, Washington
}

Manegement and Operations Contractor for the

U.S. Department of Energy under Contract DE-AC06-87RL10930

Approved for public release; distribution is unlimited 
THIS PAGE IN'TENTJONALLY LEFT BLANK 


\section{RELEASE AUTHORIZATION}

Document Number: WHC-SP-1186

Document Title: Liaison Activities with the Institute of Physical Chemistry, Russian Academy of Sciences: FY 1996

Release Date: $\quad 9 / 23 / 96$

This document was reviewed following the procedures described in WHC-CM-3-4 and is:

APPROVED FOR PUBLIC RELEASE

WHC Information Release Administration Specialist:

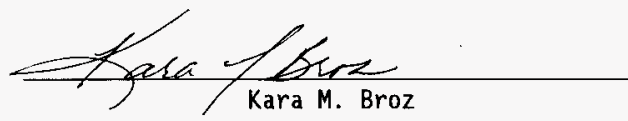

September 23, 1996 
THIS PAGE INTENTIONALLY

LEFT BLANK 
CONTENTS

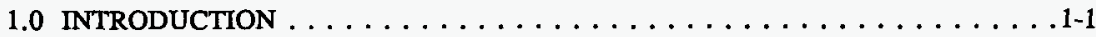

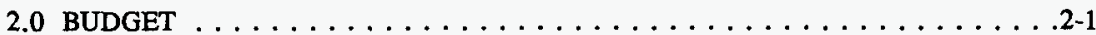

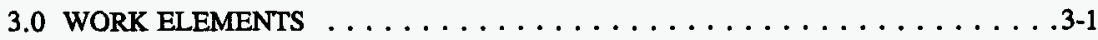

4.0 DIRECTION SUBTASK $\ldots \ldots \ldots \ldots \ldots \ldots \ldots \ldots \ldots \ldots . . \ldots \ldots \ldots .1$

4.1 TASK REVIEW AND SELECTION . . . . . . . . . . . . . 4-1

4.2 PLUTONIUM(V) STABILITY AND PROPERTIES IN ALKALI $\ldots \ldots .4$ 4-2

4.2.1 Observations by Dr. Tananaev . . . . . . . . . . 4-3

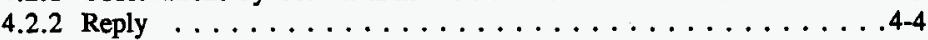

4.3 PROGRAM REVIEW AT THE IPC/RAS $\ldots \ldots \ldots \ldots \ldots \ldots \ldots$ 4-8

4.3.1 Plutonium(V) Stability . . . . . . . . . . . . . . . 4-9

4.3.2 Coprecipitation . . . . . . . . . . . . . . . 4-11

4.3.3 Catalytic Organic Oxidation and $\mathrm{Np}(\mathrm{V})$ Reduction . . . . . . 4-12

4.3.4 Fission Product and Technetium Removal from Alkaline Media . . 4-14

4.4 PROPOSED FUTURE IPC/RAS TASKS $\ldots \ldots \ldots \ldots \ldots \ldots \ldots \ldots$ 4-15 $\ldots \ldots \ldots$

4.4.1 Plutonium Precipitates in Sludge . . . . . . . . . . . 4-16

4.4.2 Actinide Sorption from Alkali on Chitins . . . . . . . . 4-16

4.4.3 Literature Review: Sodium Nitrate from Radioactive Waste . . . 4-17

4.5 TECHNICAL LITERATURE AND INFORMATION $\ldots \ldots \ldots \ldots \ldots$. . . . . .

4.6 IPC/RAS SCIENTISTS' VISIT TO THE UNITED STATES . . . . . . . 4-20

4.7 EQUIPMENT AND MATERIALS PROVIDED TO THE IPC/RAS . . . . 4-20

5.0 DISSEMINATION SUBTASK $\ldots \ldots \ldots \ldots \ldots \ldots \ldots \ldots \ldots \ldots$ 5-1

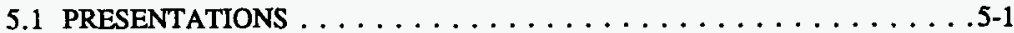

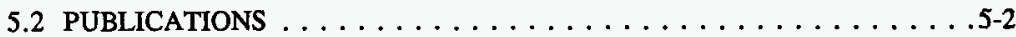

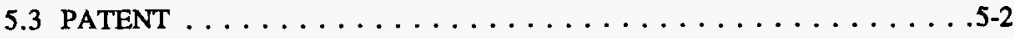

6.0 VERIFICATION SUBTASK $\ldots \ldots \ldots \ldots \ldots \ldots \ldots \ldots \ldots \ldots$ 6-1

6.1 ATTAINING EQUILIBRIUM $\ldots \ldots \ldots \ldots \ldots \ldots \ldots \ldots \ldots$ 6-1

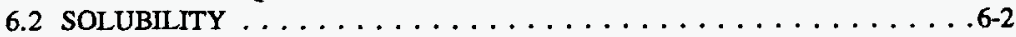

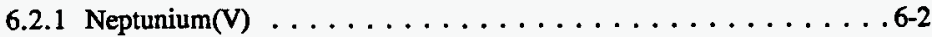

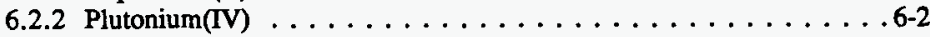

6.2 .3 Plutonium(V) . . . . . . . . . . . . . . . 6-5

6.2 .4 Plutonium(VI) ....................6-5

6.2 .5 Plutonium(IV) Carbonate $\ldots \ldots \ldots \ldots \ldots \ldots \ldots \ldots \ldots$. . . . . . . .

6.2 .6 Americium(III) $\ldots \ldots \ldots \ldots \ldots \ldots \ldots \ldots \ldots \ldots \ldots$. . . . . . . . . .

6.3 COPRECIPITATION . . . . . . . . . . . . . . . . 6-9

6.4 GAMMA RADIATION CHEMISTRY $\ldots \ldots \ldots \ldots \ldots \ldots \ldots \ldots$. . . . . . . 


\section{CONTENTS (Continued)}

7.0 ACKNOWLEDGEMENTS $\ldots \ldots \ldots \ldots \ldots \ldots \ldots \ldots \ldots \ldots \ldots \ldots \ldots$

8.0 REFERENCES $\ldots \ldots \ldots \ldots \ldots \ldots \ldots \ldots \ldots \ldots \ldots \ldots \ldots \ldots \ldots \ldots \ldots$

\section{LIST OF FIGURES}

4-1 Plutonium Hydrous Oxide Solubility Dependence on Electrode Potential in $\mathrm{NaOH} / \mathrm{NaNO}_{2}$ Solutions $\ldots \ldots \ldots \ldots \ldots \ldots \ldots \ldots \ldots \ldots$

6-1 Solubility Variation with Aging of $\mathrm{PuO}_{2} \times \mathrm{xH}_{2} \mathrm{O}$ in $5 \mathrm{M} \mathrm{NaOH} \ldots \ldots . . \ldots$. . . . .

6-2 Solubility of $\mathrm{Np}(\mathrm{V})$ Salts in $\mathrm{NaOH}$ Solutions $\ldots \ldots \ldots \ldots$

6-3 Solubility of $\mathrm{Pu}(\mathrm{IV}) \mathrm{Hydrous}$ Oxide in $\mathrm{NaOH}$ Solutions . . . . . . . . . . 6-4

6-4 Solubility of $\mathrm{Pu}(\mathrm{V})$ Salts in $\mathrm{NaOH}$ Solutions $\ldots \ldots \ldots \ldots$

6-5 Solubility of $\mathrm{Pu}(\mathrm{VI})$ Salts in $\mathrm{NaOH}$ Solutions $\ldots \ldots \ldots \ldots \ldots$

6-6 Enhancement of Plutonium Concentration Above Pu(IV) Hydrous Oxide Because of Carbonate Complexation in $\mathrm{NaOH} / \mathrm{Na}_{2} \mathrm{CO}_{3}$ Solutions $\ldots \ldots \ldots$

\section{LIST OF TABLES}

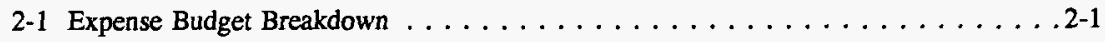

4-1 Predicted and Measured Electrode Potentials and Plutonium Concentrations

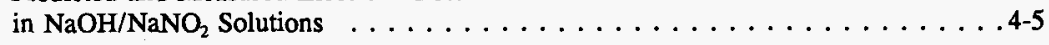

6-1 Neptunium and Plutonium Decontamination Factors from Alkaline Solution and Genuine and Simulant Hanford Site Tank Waste . . . . . . . . . . . . 6-9 


\section{LIST OF TERMS}

$\begin{array}{ll}\text { ACS } & \text { American Chemical Society } \\ \text { DF } & \text { decontamination factor } \\ \text { DOE } & \text { U.S. Department of Energy } \\ \text { ESP } & \text { Efficient Separations and Processing } \\ \text { FY } & \text { fiscal year } \\ \text { IPC/RAS } & \text { Institute of Physical Chemistry of the Russian Academy of Sciences } \\ \text { LSC } & \text { liquid scintillation counter } \\ \text { MAR } & \text { Method of Appearing Reagents } \\ \text { PNNL } & \text { Pacific Northwest National Laboratory } \\ \text { SRTC } & \text { Savannah River Technical Center }\end{array}$


This page intentionally left blank. 


\section{LIAISON ACTIVITIES WITH THE INSTITUTE OF PHYSICAL CHEMISTRY, RUSSIAN ACADEMY OF SCIENCES: FY 1996}

\subsection{INTRODUCTION}

The task "IPC/RAS Liaison and Tank Waste Testing" is a program being conducted in fiscal year (FY) 1996 with the support of the U.S. Department of Energy (DOE) Office of Science and Technology, EM-53 Efficient Separations and Processing (ESP) Crosscutting Program, under the technical task plan RL46C342. The principal investigator is Cal Delegard of the Westinghouse Hanford Company. The task involves a technical liaison with the Institute of Physical Chemistry of the Russian Academy of Sciences (IPC/RAS) and their DOE-supported investigations into the fundamental and applied chemistry of the transuranium elements (primarily neptunium, plutonium, and americium) and technetium in alkaline media.

The task has three purposes:

1. Providing technical information and technical direction to the IPC/RAS.

2. Disseminating IPC/RAS data and information to the DOE technical community.

3. Verifying IPC/RAS results through laboratory testing and comparison with published data.

This report fulfills the milestone "Provide End-of-Year Report to Focus Area," due September 30, 1996. 
WHC-SP-1186

This page intentionally left blank. 


\subsection{BUDGET}

The total task funding was $\$ 250,000$ of which $\$ 50,000$ was allocated to capital purchases. The capital monies were intended for the acquisition and delivery of a liquid scintillation counter (LSC) to the IPC/RAS.

Task expense budget accounts (labor, travel, sample analysis, publishing services, organizational overheads) total $\$ 200,000$ for FY 1996. The status through September 16, 1996 is given in Table 2-1. The increased amount spent in the travel budget was because four, rather than two, IPC/RAS scientists were brought to the United States for discussions. Expenditures for publishing also were above the projected rate. The higher spending for travel and publishing was balanced by markedly lower spending in labor and sample analysis. Savings on labor and sample analysis were achieved by extensive use of published data, rather than separate laboratory studies, to verify IPC/RAS results.

Table 2-1. Expense Budget Breakdown.

\begin{tabular}{|c|c|c|c|}
\hline (6) & Bngor & (6) S Hrough & I) \\
\hline Labor & 80,000 & 62,700 & 17,300 \\
\hline Travel & 21,900 & 34,700 & $(12,800)$ \\
\hline Sample Analysis & 44,000 & 4,700 & 39,300 \\
\hline Publishing Services & 13,200 & 28,900 & $(15,700)$ \\
\hline Organization Overhead & 17,900 & 13,900 & 4,000 \\
\hline Contracts \& Purchases & 0 & 1,700 & $(1,700)$ \\
\hline G\&A/CSP" & 23,000 & 24,000 & $(1,000)$ \\
\hline Total & 200,000 & 170,600 & 29,400 \\
\hline
\end{tabular}

Note:

"General and administrative/common support pool Hanford Site overhead charges.

Because of these economies, the task will have an estimated $\$ 15,000$ expense budget remaining unspent at the end of the fiscal year on September 30, 1996. Attempts are underway to carry the unspent funds to the task in FY 1997.

By order of the DOE Richland Operations Office in August 1996, the liaison task will be transferred to the Pacific Northwest National Laboratory (PNNL) from the Project Hanford 
successor to Westinghouse Hanford Company beginning FY 1997. The transfer was not anticipated when FY 1997 funding for the task was requested in April 1996. Because labor rates at PNNL are significantly higher than estimated for the Project Hanford successor, some decrease in task activity, primarily by the liaison scientist, is anticipated. The additional funding provided by the proposed $\$ 15,000$ carry-over can offset part of the impact of the higher labor rates.

Additional capital funds $(\$ 15,000)$ were requested early in FY 1996 to cover the higher-than-anticipated costs of the LSC $(\$ 52,000$ for the delivered instrument indicated by two candidate vendors versus about $\$ 35,000$ estimated delivered cost; overhead charges not included). Through the efforts of this task and the Westinghouse Hanford Company procurement organization, a third prominent manufacturer of LSC devices with a sales and service office in Moscow, Russia was located. This vendor offered a suitable LSC instrument unburdened by the approximately $\$ 20,000$ surcharge apparently imposed by the two other candidate vendors to deliver in Moscow, Russia, rather than the United States. The LSC was purchased, delivered, and installed at the IPC/RAS in February at a cost of about $\$ 42,200$ (including delivery and Westinghouse Hanford Company procurement overhead charges). The $\$ 15,000$ additional capital funds were returned to the program for reallocation. 


\subsection{WORK ELEMENTS}

The following three work elements were identified and described in the technical task plan.

1. Direct the IPC/RAS principal investigators by review and guidance in the creation and performance of the IPC/RAS tasks. This work element also includes provision of difficult-to-obtain DOE contractor documents and information on the Hanford Site tank waste properties and system and supply of essential laboratory equipment and materials to the IPC/RAS.

2. Disseminate the IPC/RAS results by technical review, editing, and publication of the IPC/RAS reports and presentation of the IPC/RAS results at program, DOE Site, national, and international meetings and symposia.

3. Verify the results of the IPC/RAS work by studies of the technical literature and performance of laboratory tests with simulant and genuine Hanford Site tank waste. 
WHC-SP-1186

This page intentionally left blank. 


\subsection{DIRECTION SUBTASK}

Activities under the direction subtask included a review and critique of the tasks proposed by the IPC/RAS for FY 1996, provision of technical literature and information to the IPC/RAS scientists, a visit of the four IPC/RAS scientists to the United States for discussions with DOE and DOE contractor personnel, program review at the IPC/RAS, technical dialogues, and supply of the LSC and other equipment and materials to the IPC/RAS.

\subsection{TASK REVIEW AND SELECTION}

Eight proposals were made by the IPC/RAS for work in FY 1996. The eight proposals, as well as the names of the laboratory heads ("managers") and lead scientists, if different from the laboratory head, were provided late in FY 1995 (Delegard 1995b):

1. Investigation of the stability of plutonium(V). (Krot/Budantseva)

2. Investigation of the effects of tank waste anions (for example, nitrate, nitrite, carbonate, complexants) on the removal of actinides from solution by the Method of Appearing Reagents; determination of the behaviors of ${ }^{90} \mathrm{Sr}$ and ${ }^{137} \mathrm{Cs}$ is these reactions. (Krot/Bessonov)

3. Investigation of homogeneous and heterogeneous catalysis (Krot/Shilov) - to destroy organic compounds in Hanford Site tank waste - to reduce and stabilize neptunium in the (IV) state.

4. Investigation of isolation methods for technetium (anion exchange, extraction, coprecipitation, cementation on metals, electrodeposition). (Peretrukhin)

5. Investigation of sorbents prepared from lanthanum and uranium hydroxide with inert carriers for neptunium, plutonium, and americium. (Krot/Tananaev)

6. Investigation of technetium response to thermochemical processing. (Kryutchkov)

7. Investigation of electrochemical denitration of waste in the presence of uranium, neptunium, plutonium, technetium, and chromate. (Peretrukhin)

8. Investigation of alpha radiolysis on actinide behavior in alkaline and alkaline/carbonate media. (Pikaev)

Critiques and comments were provided to the IPC/RAS in November 1995 on the scope, utility, and, for some projects, the likelihood of support. In addition, some DOE contractor technical reports were provided at this time to advise the IPC/RAS scientists of related work 
already performed in these areas. A separate technical dialogue between Cal Delegard (the liaison principal investigator) and the IPC/RAS scientist Dr. Ivan G. Tananaev also took place. This exchange concerned the stability of pentavalent plutonium in alkaline media.

As a result of these remarks and reports, task \#5 (on sorbents) was withdrawn because similar work already had been performed by the Sandia and Los Alamos National Laboratories. Task \#6 (on technetium behavior in thermochemical processing) also was withdrawn based on advice that calcination processing of Hanford Site tank waste was unlikely. The discussions between Dr. Tananaev and Cal Delegard were taken into account in designing the studies proposed for task $\# 1$. The major points of these discussions are given in Section 4.2.

Modifications to the remaining six tasks were made and more detailed proposals (including cost and schedule) were submitted in November and December 1995. Recommendations were made to the DOE and to Dr. Jack Watson, the Program Coordinator for International Programs, about which tasks to support. The four most favored tasks were \#1 (stability of pentavalent plutonium), $\# 2$ (continued studies of coprecipitation by the Method of Appearing Reagents), \#3 (catalytic methods to destroy organics and reduce neptunium), and \#4 (technetium removal methods). These four tasks were selected for support.

Contract negotiations were made and concluded by Dr. Tom Albert of Thomas Albert and Associates, Palm Harbor, Florida. The IPC/RAS work on the four tasks commenced on March 1, 1996.

\subsection{PLUTONIUM(V) STABILITY AND PROPERTIES IN ALKALI}

A technical dialogue between Dr. Ivan G. Tananaev of the IPC/RAS and Cal Delegard was initiated during Delegard's visit to the IPC/RAS in August 1995, and it continued by a FAX exchange in autumn 1995. At issue, was the chemistry of pentavalent plutonium in alkaline solution. The stability of Pu(V) in alkaline solution was observed by IPC/RAS scientists to be lower than would be expected by simple consideration of the measured $\mathrm{Pu}(\mathrm{V})-\mathrm{Pu}(\mathrm{IV})$ formal potentials in alkali metal ( $\mathrm{Li}, \mathrm{Na}$ ) hydroxide solutions.

The IPC/RAS scientists observed the relative instability of dissolved $\mathrm{Pu}(\mathrm{V})$ in coprecipitation reactions reported by Krot et al. (1996), in oxidation/reduction studies reported by Shilov et al. (1996), and in Pu(V) salt solubility tests reported by Peretrukhin et al. (1996). Each report suggested that the instability of $\mathrm{Pu}(\mathrm{V})$, shown by its propensity to convert to $\mathrm{Pu}(\mathrm{IV})$ hydrous oxide of low solubility, was caused by its disproportionation to $\mathrm{Pu}(\mathrm{IV})$ and Pu(VI).

On the other hand, electrochemical studies show $\mathrm{Pu}(\mathrm{V})$ is stable to disproportionation in alkaline media (Bourges 1972; Peretrukhin and Alekseeva 1974; Peretrukhin et al. 1994; and Maslennikov et al. 1993). Furthermore, Bourges (1972) observed that $\mathrm{Pu}(\mathrm{V})$ forms by reproportionation when freshly precipitated $\mathrm{Pu}(\mathrm{TV})$ hydrous oxide and dissolved $\mathrm{Pu}(\mathrm{VI})$ are 
mixed in alkaline solution. Optical absorption spectra attributed to $\mathrm{Pu}(\mathrm{V})$ in alkaline solution also have been gathered (Bourges 1972 and Delegard 1985). These observations on the stability of $\mathrm{Pu}(\mathrm{V})$ in alkaline media have been summarized in a review of the chemistry of actinides in alkaline media (Peretrukhin et al. 1995).

\subsubsection{Observations by Dr. Tananaev}

In an October 25, 1995 FAX, Dr. Tananaev cited a number of observations leading him to believe that $\mathrm{Pu}(\mathrm{V})$ is unstable in alkaline media:

- Plutonium concentrations increase with increasing hydroxide concentration both in the presence and in the absence of reductants; therefore, Pu(IV) oxidative dissolution (to form $\mathrm{Pu}(\mathrm{V})$ dissolved species) is not required to explain the apparent increased solubility of $\mathrm{PuO}_{2} \cdot \mathrm{xH}_{2} \mathrm{O}$.

- Neptunium(V) and (VI), americium(V) and (VI), and plutonium(VI) give spectra whose peak intensities decrease about 20 -fold and whose locations shift about $30 \mathrm{~nm}$ towards higher wavelengths in changing from $0.1 \mathrm{M} \mathrm{HClO}_{4}$ solution to $1 \mathrm{M}$ alkali. These decreases in optical absorption at high hydroxide concentrations have been attributed to the formation of centrosymmetric octahedral pentavalent or hexavalent species of the form $\left[\mathrm{AnO}_{2}(\mathrm{OH})_{4}\right]^{3-2-2-}$, respectively (refer to Tananaev 1989,1990 , and 1994). ${ }^{1}$

In alkaline solution, the analogous $\mathrm{Pu}(\mathrm{V})$ hydroxide complex should have peak absorption near $610 \mathrm{~nm}$ with a molar extinction coefficient, $\epsilon$, of less than 1 $\mathrm{M}^{-1} \mathrm{~cm}^{-1}$ based on the $575 \mathrm{~nm}$ band, $\epsilon$ of $20 \mathrm{M}^{-1} \mathrm{~cm}^{-1}$, for $\mathrm{Pu}(\mathrm{V})$ in acid solution. For this reason, the spectra attributed to $\mathrm{Pu}(\mathrm{V})$ published by Bourges (1972) and Delegard (1985), with numerous sharp absorption lines having molar extinction coefficients of 5 to $13 \mathrm{M}^{-1} \mathrm{~cm}^{-1}$, cannot be caused by the purported $\mathrm{Pu}(\mathrm{V})$. Instead, the peaks may be attributed to $\mathrm{Pu}(\mathrm{IV})$ in a mixture of $\mathrm{Pu}(\mathrm{IV})$ and $\mathrm{Pu}(\mathrm{VI})$ species.

\footnotetext{
${ }^{1}$ The sharp $f-f$ electronic transitions in actinides and lanthanides normally are forbidden by (LaPorte) symmetry rules and thus are weak if they exist at all. Asymmetries introduced to the f-electron shell by imposition of an asymmetric ligand field cause a relaxation of these rules and lead to the sharp optical absorptions observed in lanthanide and actinide spectra. The decreasing absorptions of the $\mathrm{Np}(\mathrm{V}$ and VI), $\mathrm{Am}(\mathrm{V}$ and VI), and Pu(VI) hydroxide complexes, as hydroxide concentration increases, are evidence of formation of centrosymmetric ligand fields. The symmetry is attributed to tetrahydroxide actinyl complexes in which the hydroxide are arranged equatorially and symmetrically around the linear central actinyl ion.
} 
- The redox potential of $\mathrm{Pu}(\mathrm{IV}) /(\mathrm{V})$ in alkali may be calculated based on the potential in acid and the solubility products of the formed Pu(TV) oxide and $\mathrm{Pu}(\mathrm{V})$ hydroxide. The calculated $\mathrm{Pu}(\mathrm{IV}) /(\mathrm{V})$ potential is about 0.6 volts and indicates $\mathrm{Pu}(\mathrm{V})$ would disproportionate. In contrast, the potential measured by Peretrukhin and colleagues is about -0.6 volts.

- The potential of the Np(IV)/(V) couple measured by Peretrukhin and Spitsyn (1982), -0.95 volts, is too low based on reproportionation equilibrium constants determined by Professor Shilov in unpublished work. Using the reproportionation measurements, the potential should be about 0.113 volts. The analogous plutonium potential should be similar.

- The potential of the $\mathrm{Pu}(\mathrm{TV}) /(\mathrm{V})$ couple is about 0.4 volts in carbonate media. The $\mathrm{Pu}(\mathrm{IV}) /(\mathrm{V})$ potential in hydroxide media should be similar to this value.

- Addition of stoichiometric amounts of hydrazine (or substoichiometric amounts in the presence of low hydroxide concentrations) to preparations of $\mathrm{Na}_{2} \mathrm{PuO}_{2}(\mathrm{OH})_{3} \cdot \mathrm{xH}_{2} \mathrm{O}$ gives acid-insoluble green compounds having solubilities in alkali of about $10^{-6}$ to $10^{-7} \mathrm{M}$. These results indicate $\mathrm{Pu}(\mathrm{IV})$ solids form readily by reduction of $\mathrm{Pu}(\mathrm{V})$ salts by hydrazine, even with insufficient amounts of hydrazine.

\subsubsection{Reply}

A reply to Dr. Tananaev's observations was made by Cal Delegard in a November 9, 1995 FAX. The FAX pointed out that the reactions measured by Peretrukhin and colleagues for the reduction of $\mathrm{Pu}(\mathrm{V})$ to $\mathrm{Pu}(\mathrm{IV})$ were irreversible and proceeded to very freshly formed $\mathrm{Pu}(\mathrm{IV})$. The $\mathrm{Pu}(\mathrm{IV})$ then rapidly precipitated on the electrode (as reported). The formed solids then could undergo olation (oxygen bridging) and crystallization reactions. With increasing time and crystallization, the potential for the reverse oxidation reaction, $\mathrm{Pu}^{\mathrm{IV}} \mathrm{O}_{2} \cdot \mathrm{xH}_{2} \mathrm{O} \rightarrow \mathrm{Pu}(\mathrm{V})$, would become increasingly positive and would be well above the potential of the purely aqueous phase $\mathrm{Pu}(\mathrm{V}) \rightarrow \mathrm{Pu}(\mathrm{IV})$ reaction measured by Peretrukhin and colleagues. In other words, because of the precipitation (and the stability) of the Pu(IV) solid phase, the electrochemical measurements of Peretrukhin and colleagues cannot, by themselves, reflect the extent of oxidative dissolution of Pu(IV) hydrous oxide to form Pu(V) solution species.

It was also noted that unless the $\mathrm{PuO}_{2}(\mathrm{am}) / \mathrm{Pu}(\mathrm{V})$ potential increases above the $\mathrm{Pu}(\mathrm{V}) / \mathrm{Pu}(\mathrm{VI})$ potential (given as 0.21 volts in $1 \mathrm{M} \mathrm{NaOH}$ [Peretrukhin and Spitsyn 1982]), disproportionation cannot occur. 


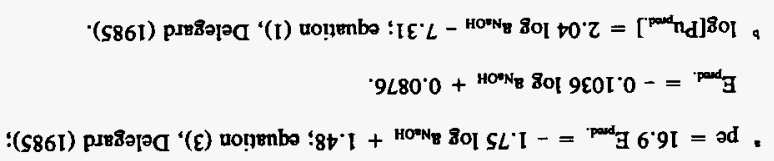

:sפTON

\begin{tabular}{|c|c|c|c|c|c|c|c|c|}
\hline $80 t^{\circ} 0$ & $t 98^{\circ} \vdash-$ & ESZ'S- & sloo- & $\angle E 0^{\circ} 0^{-}$ & $250^{\circ} 0^{-}$ & Z8'SI & $00 . I$ & $00 \mathrm{~L}$ \\
\hline$S S L O$ & S80 S- & $\angle 0 Z \cdot S-$ & $110^{\circ} 0^{-}$ & $\$ 20^{\circ} 0^{-}$ & $9 \varepsilon 0^{\circ} 0^{-}$ & ZE’ZI & $00 \%$ & 00.9 \\
\hline EEIO & $9 S I^{\circ} \mathrm{S}-$ & $2 \varepsilon 0^{\circ} 9^{-}$ & $\varepsilon \varepsilon 0^{\circ} 0^{-}$ & $220^{\circ} 0^{-}$ & $\mathrm{SSO}^{\circ} \mathrm{O}^{-}$ & $\angle E^{\prime} I I$ & $00^{\circ} t$ & 00.5 \\
\hline SLZO & ZEE'S- & ع68. S- & $\varepsilon 20^{\circ} 0^{-}$ & $\varepsilon 10^{\circ} 0^{-}$ & $9 \varepsilon 0^{\circ} 0^{-}$ & $2 \varepsilon^{\circ} 6$ & $00^{\circ} \varepsilon$ & $00 . s$ \\
\hline$Z L I^{\circ} 0$ & ZEE S- & $\angle 60^{\circ} 9^{-}$ & $\mathfrak{E} \mathfrak{E O}^{\circ} 0^{-}$ & $\varepsilon 10^{\circ} 0^{-}$ & $960^{\circ} 0^{-}$ & $z \varepsilon^{\circ} 6$ & $00^{\circ} \varepsilon$ & $00-s$ \\
\hline$\$ 6 I^{\circ} 0$ & EOS $\mathcal{S}^{\circ}$ & $9129-$ & $+10^{\circ} 0^{-}$ & $500^{\circ} 0^{-}$ & $810^{\circ} 0^{-}$ & $69^{\circ} \mathrm{L}$ & $00^{\circ} 2$ & 00.5 \\
\hline I9E: 0 & $9 S S^{*} \mathrm{S-}$ & $666^{\circ} \mathrm{S}-$ & $\mathrm{SOO}^{\circ} \mathrm{O}^{-}$ & $100^{\circ} 0^{-}$ & $900^{\circ}-$ & $\nabla \tau \cdot L$ & OS'I & $00 \mathrm{~s}$ \\
\hline StS:0 & $t+9^{\circ} \mathrm{S}^{-}$ & $\angle 06 \mathrm{~S}$ & $900^{\circ} 0^{-}$ & $\varepsilon 00^{\circ} 0$ & $800^{\circ} 0^{-}$ & $95^{\circ} 9$ & $00^{\circ}$ I & $00 \mathrm{~s}$ \\
\hline S6I'0 & LI9'S- & 9zE'9- & $910^{\circ} 0^{-}$ & $200^{\circ} 0$ & $\$ 10^{\circ} 0_{-}^{-}$ & $9 L 99$ & $00^{\circ} t$ & $00^{\circ} t$ \\
\hline (x) & 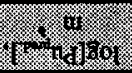 & (4) & \% & (1) & (2) & 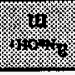 & \% & 6.8. \\
\hline
\end{tabular}

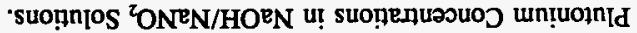

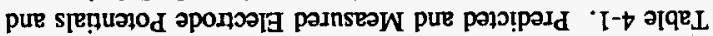

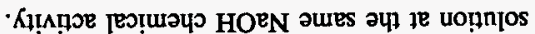

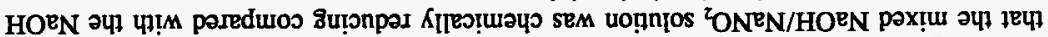

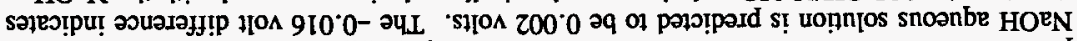

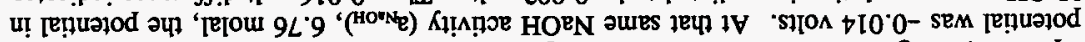
pəInseəu әч "

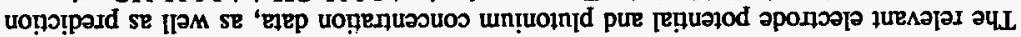

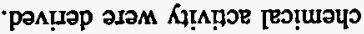

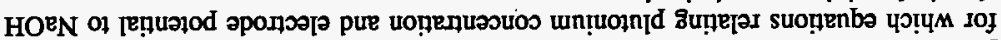

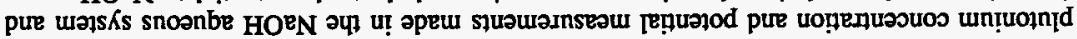

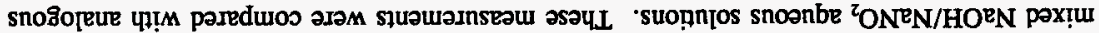

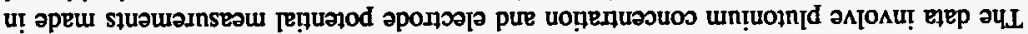

•әЈу pәz!reuuns

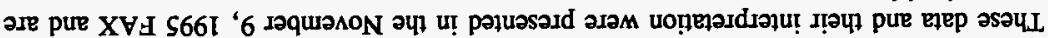

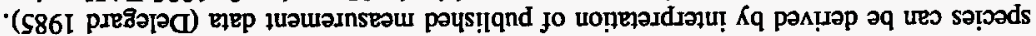

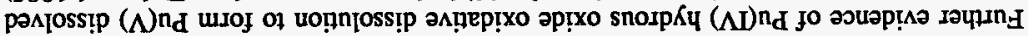


Similarly, for the $4 \mathrm{M} \mathrm{NaOH} / 4 \mathrm{M} \mathrm{NaNO}_{2}$ solution, the measured plutonium solution concentration was $10^{-6.326}\left(4.72 \times 10^{-7}\right)$ molal, about $20 \%$ of the $10^{-5.617}\left(2.42 \times 10^{-6}\right)$ molal concentration predicted in $\mathrm{NaOH}$ solution at the same $\mathrm{NaOH}$ chemical activity. As argued previously (Delegard 1985), the chemically reducing conditions imposed by $\mathrm{NaNO}_{2}$ appeared to inhibit the oxidative dissolution of $\mathrm{Pu}^{(\mathrm{IV})} \mathrm{O}_{2} \cdot \mathrm{xH}_{2} \mathrm{O}$.

Graphical interpretation of the data given in Table 4-1 may be performed to correlate the decrease in plutonium solution concentration with the decrease in electrode potential. As shown in the following arguments, the logarithm of the ratio of plutonium solution concentrations in the mixed $\mathrm{NaOH} / \mathrm{NaNO}_{2}$ and $\mathrm{NaOH}$ systems, divided by the difference in the electrode potentials, is proportional to the number of electrons participating in the proposed oxidative dissolution of the observed $\mathrm{Pu}$ (IV) hydrous oxide solid phase:

$$
\text { y } \mathrm{OH}^{-}+\mathrm{PuO}_{2}(\mathrm{~s}) \rightleftharpoons \mathrm{PuO}_{2}(\mathrm{OH})_{\mathrm{y}}^{(\mathrm{y}-\mathrm{n})-}+\mathrm{ne}^{-} .
$$

The following equilibrium equation represents the oxidative dissolution reaction:

$$
\mathrm{K}=\frac{[\mathrm{Pu}]\left(\mathrm{e}^{-}\right)^{\mathrm{n}}}{\left(\mathrm{OH}^{-}\right)^{\mathrm{y}}}
$$

In equation (1), $\mathrm{K}$ is the equilibrium constant, $[\mathrm{Pu}]$ represents the molal concentration of the plutonium complex, $\left(\mathrm{e}^{-}\right)$is the electron activity, $\mathrm{n}$ is the number of electrons involved in the oxidation reaction, $\left(\mathrm{OH}^{-}\right)$is the hydroxide ion activity, and $y$ is the number of hydroxide ions involved in formation of the dissolved plutonium complex.

At a fixed hydroxide ion activity (taken to be proportional to the sodium hydroxide activity), equation (1) may be simplified:

$$
\mathrm{K}^{*}=[\mathrm{Pu}]\left(\mathrm{e}^{-}\right)^{\mathbf{n}}
$$

where $\mathrm{K}^{\bullet}$ is a conditional equilibrium constant incorporating the hydroxide activity term. Thus, at equal hydroxide activities, this equation holds for both the $\mathrm{NaOH}$ aqueous system and the $\mathrm{NaOH} / \mathrm{NaNO}_{2}$ aqueous system since only electron activities and plutonium concentrations are involved. Therefore:

$$
\mathrm{K} \cdot=[\mathrm{Pu}]\left(\mathrm{e}^{-}\right)^{\mathrm{n}}=[\mathrm{Pu}]^{\prime}\left(\mathrm{e}^{-}\right)^{\prime \mathrm{n}}
$$

where the prime (') marks indicate the $\mathrm{NaOH} / \mathrm{NaNO}_{2}$ system. Equation (3) may be rearranged:

$$
\frac{[\mathrm{Pu}]^{\prime}}{[\mathrm{Pu}]}=\frac{\left(\mathrm{e}^{-}\right)^{\mathrm{n}}}{\left(\mathrm{e}^{-}\right)^{\prime \mathbf{n}}}
$$


or, taking logarithms:

$$
\log \frac{[\mathrm{Pu}]^{\prime}}{[\mathrm{Pu}]}=n \log \frac{\left(\mathrm{e}^{-}\right)}{\left(\mathrm{e}^{-}\right)^{\prime}}=n\left[\log \left(\mathrm{e}^{-}\right)-\log \left(\mathrm{e}^{-}\right)^{\prime}\right]
$$

The logarithm of the electron activity is related to the electrode potential by the equation:

$$
\log \left(e^{-}\right)=\frac{-E}{0.05916}
$$

Equation (6) may be used to reformulate equation (5) as follows:

$$
\log \frac{[\mathrm{Pu}]^{\prime}}{[\mathrm{Pu}]}=\mathrm{n}\left[\log \left(\mathrm{e}^{-}\right)-\log \left(\mathrm{e}^{-}\right)^{\prime}\right]=\frac{n}{0.05916}\left(\mathrm{E}^{\prime}-\mathrm{E}\right)
$$

where $\mathrm{E}$ and $\mathrm{E}^{\prime}$ are the electrode potentials in the $\mathrm{NaOH}$ and $\mathrm{NaOH} / \mathrm{NaNO}_{2}$ systems, respectively, at a given sodium hydroxide activity. In terms of the values given in Table 4-1 for the measured $\left(\mathrm{NaOH} / \mathrm{NaNO}_{2}\right)$ and predicted $(\mathrm{NaOH})$ plutonium concentrations and electrode potentials, equation (7) becomes:

$$
\log \frac{\left[\mathrm{Pu}_{\text {meas. }}\right]}{\left[\mathrm{Pu} u_{\text {prod. }}\right]}=\frac{n}{0.05916}\left(\mathrm{E}_{\text {mees. }}-\mathrm{E}_{\text {prod. }}\right)
$$

Therefore, plotting the logarithm of the ratio of the plutonium concentrations (measured in the $\mathrm{NaOH} / \mathrm{NaNO}_{2}$ system and predicted from the $\mathrm{NaOH}$ system at the same sodium hydroxide activity) versus the difference of the measured $\left(\mathrm{NaOH} / \mathrm{NaNO}_{2}\right)$ and predicted $(\mathrm{NaOH})$ electrode potentials gives a slope of $\mathrm{n}$, the number of electrons involved in the oxidative dissolution of $\mathrm{PuO}_{2} \cdot \mathrm{xH}_{2} \mathrm{O}$, divided by 0.05916 .

The plot of these plutonium concentration and electrode potential values (see Table 4-1) is presented according to equation (8) in Figure 4-1.

The best-fit linear regression of the data is displayed as a straight line through the data points. The line follows the equation:

$$
\log \frac{\left[\mathrm{Pu}_{\text {mases. }}\right]}{\left[\mathrm{Pu}_{\text {pros. }}\right]}=-0.236+17.432\left(\mathrm{E}_{\text {meas. }}-\mathrm{E}_{\text {pred. }}\right)
$$


Figure 4-1. Plutonium Hydrous Oxide Solubility Dependence on Electrode Potential in $\mathrm{NaOH} / \mathrm{NaNO}_{2}$ Solutions.

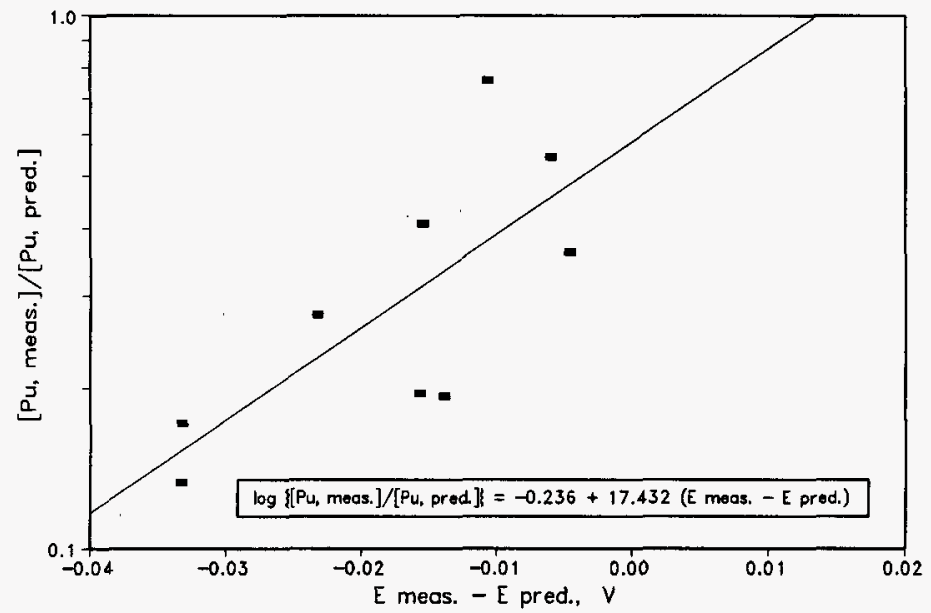

The slope is 17.4 ( \pm 6.1 ). Thus, the number of electrons, $n$, involved in the oxidative dissolution is:

$$
\mathrm{n}=0.05916 \times 17.4( \pm 6.1)=1.03( \pm 0.36) \cong 1
$$

This analysis therefore supports the original contention (Delegard 1985) that the dissolution of $\mathrm{PuO}_{2} \cdot \mathrm{xH}_{2} \mathrm{O}$ in highly alkaline media proceeds by a one-electron oxidation to form $\mathrm{Pu}(\mathrm{V})$ dissolved species.

\subsection{PROGRAM REVIEW AT THE IPC/RAS}

A technical program review was conducted during a visit to the IPC/RAS June 17 to 25 , 1996. The program review was performed by Cal Delegard, liaison, and Dr. James R. Jewett, Manager, Process Chemistry and Statistics, Westinghouse Hanford Company. The program review encompassed individual reviews of the four FY 1996 IPC/RAS tasks (stability of pentavalent plutonium, continued studies of coprecipitation, catalytic methods to destroy organics and reduce neptunium, and technetium removal methods). A visit to the radioactive waste research and treatment facility "Radon" also took place during the visit. 


\subsubsection{Plutonium(V) Stability}

Interest in the stability of plutonium(V) in alkaline media is rooted in the significance of plutonium as a component of tank waste and the central importance of plutonium(V) stability in the solubility and behavior of plutonium hydrous oxide compounds in alkaline solution. The principal investigator for this task is Dr. N. Budantseva, a member of Professor Nikolai N. Krot's Transuranium Elements Laboratory. Discussions were held with Professor Krot, Dr. Budantseva, Professor Vladimir P. Shilov, Dr. Tananaev, and Dr. A. M. Fedoseev. Dr. Fedoseev led the discussions on Dr. Budantseva's task since Dr. Budantseva does not speak English.

To determine the stability of Pu(V) reliably, fundamental studies on the preparation and identification of relevant species must first be performed. It is important to be able to identify the solid phases and the oxidation states of the dissolved species. Preparation of $\mathrm{Pu}(\mathrm{V})$ solutions and compounds in strong alkali also is required. Initial results of the fundamental studies were presented.

The absorption spectrum of $\mathrm{Pu}(\mathrm{VI})$ in alkaline solution was determined. By interpretation of the spectra, it was found that only one species apparently exists in solutions from 2 to over $10 \mathrm{M} \mathrm{NaOH}$; the Beer-Lambert law also is obeyed (i.e., the absorbance is proportional to the concentration). The principal absorption is a charge transfer band beginning in the near ultraviolet. No f-f transitions (characterized by sharp absorbance lines) are evident. Plutonium(VI) is stable in aqueous solution in this concentration range and does not oxidize water even with heating at $95^{\circ} \mathrm{C}$ for three to five hours despite having a $\mathrm{Pu}(\mathrm{VI}) / \mathrm{Pu}(\mathrm{V})$ potential of about 0.2 to 0.3 volts. At less than $2 \mathrm{M} \mathrm{NaOH}$, however, $\mathrm{Pu}(\mathrm{VI})$, introduced as acid solution, becomes brown-yellow in color, "unstable", and precipitates. This may be because the amount added is equivalent to about $10^{-3} \mathrm{M} \mathrm{Pu}$ and exceeds the solubility of $\mathrm{Pu}$ (VI) salts (see section 6.2.4). However, if the $\mathrm{Pu}(\mathrm{VI})$ in less than $2 \mathrm{M} \mathrm{NaOH}$ is produced by reduction of $\mathrm{Pu}$ (VII) or by dilution of more concentrated $\mathrm{Pu}(\mathrm{VI}) / \mathrm{NaOH}$ solutions, the $\mathrm{Pu}(\mathrm{VI})$ is "stable" and the solution color is yellow-green.

Subsequent discussions with Prof. Krot and Dr. Tananaev on this topic were conducted. Professor Krot suggested that the structure of $\mathrm{Pu}(\mathrm{VI})$ in strongly alkaline solution may be similar to that of $\mathrm{Pu}(\mathrm{VII})$; i.e., $\left[\mathrm{PuO}_{4}(\mathrm{OH})_{2}\right]^{4-}$, not $\left[\mathrm{PuO}_{2}(\mathrm{OH})_{4}\right]^{2-}$. This would explain the reversibility of the $\mathrm{Pu}(\mathrm{VI}) / \mathrm{Pu}$ (VII) couple. The evident conversion to another dissolved species of $\mathrm{Pu}(\mathrm{VI})$ at low hydroxide concentrations might then be attributed to formation of the $\left[\mathrm{PuO}_{2}(\mathrm{OH})_{4}\right]^{2-}$ species.

As related by Dr. Fedoseev, tests of addition of Pu(IV) hydroxide precipitates to Pu(VI) in alkali solution have not been performed. This reaction was investigated and reported by Bourges (1972); "reproportionation" to form Pu(V) was observed when freshly-prepared Pu(IV) hydroxide was used. Professor Krot believes the position of this reproportionation equilibrium is highly dependent on the age and crystallinity of the Pu(IV) hydroxide. 
Kinetically rapid reductants having known stoichiometry for reaction with $\mathrm{Pu}(\mathrm{VI})$ would be useful in the preparation of alkaline solutions of Pu(V). Tests to identify such reductants were performed. Reductants tested included iodide, dithionite, and V(IV). None of these was found to be completely satisfactory. Tin(II) also is being considered but had not been tested. Electrochemical reduction of $(2$ to 5$) \times 10^{-3} \mathrm{M} \mathrm{Pu}(\mathrm{VI})$ is also unsatisfactory because the electrodes are fouled by precipitates. The precipitates likely are Pu(V) sodium salts given that their solubilities are about $(1$ to 4$) \times 10^{-4} \mathrm{M}$.

Another method to introduce $\mathrm{Pu}(\mathrm{V})$ would be by dissolution of appropriate $\mathrm{Pu}(\mathrm{V})$ double salts; e.g., $\mathrm{KPuO}_{2} \mathrm{CO}_{3}$ and $\mathrm{Na}_{2} \mathrm{PuO}_{2}(\mathrm{OH})_{3}$. Preparation of the sodium hydroxide complex compound, by hydrazine or iodide reduction of $\mathrm{Pu}(\mathrm{VI})$, must be performed in high hydroxide concentrations to avoid Pu(IV) formation. Because of this, the resulting product is difficult to purify and store. The potassium double salt also is not ideal because unwanted carbonate and potassium are introduced.

Professor Shilov is investigating peroxide to reduce Pu(VI). The stoichiometry is known (two electrons per peroxide) but self-decomposition of peroxide compromises exact chemical balance. The rate, completeness, and effects of alkali concentration, temperature, and presence of other salts on the peroxide reaction will be determined in forthcoming work.

Plutonium(V) may sorb on solids. The possible sorption of $\mathrm{Pu}(\mathrm{V})$ was investigated using the beta-emitting isotope ${ }^{239} \mathrm{~Np}(\mathrm{~V})$ as an unambiguous surrogate for $\mathrm{Pu}(\mathrm{V})$. Equimolar Pu(VI) and $\mathrm{Np}(\mathrm{V})$ were mixed with hydroxylamine reductant in 2 to $8 \mathrm{M} \mathrm{NaOH}$ solutions, aged at different temperatures $\left(40,50,60^{\circ} \mathrm{C}\right)$, and sampled. Hydroxylamine was used because it should reduce $\mathrm{Pu}(\mathrm{VI})$ to $\mathrm{Pu}(\mathrm{IV})$ but not reduce $\mathrm{Np}(\mathrm{V})$. Tests also were performed with mole ratios of $\mathrm{Np}(\mathrm{V}): \mathrm{Pu}(\mathrm{VI})$ of $1: 1,10: 1$, and $20: 1$. Some sorption or coprecipitation was observed under all conditions, increasing slightly as hydroxide concentration decreased or as temperature increased. However, the amount of $\mathrm{Np}(\mathrm{V})$ sorbed was no more than half and that only after three hours' contact.

Dr. Tananaev described his ongoing work to determine the valence states of plutonium present in solid compounds. This approach relies on the dissolution of the compounds in perchloric acid and using spectrophotometry to identify the oxidation state. The experiments began with the precipitation of $\mathrm{Pu}(\mathrm{IV})$ hydroxide, introduced as $\mathrm{Pu}(\mathrm{IV})$ nitrate in nitric acid, in $\mathrm{NaOH}$ of varying concentrations. The precipitates were aged for either 3 or 96 hours at either 25 or $100^{\circ} \mathrm{C}$. The solids were separated by centrifugation and washing, to pH neutrality, using 50:50 ethanol:water (washing with pure water would result in peptization and incomplete solids separation). The solids were then dissolved in 0.05 to $1 \mathrm{M} \mathrm{HClO}_{4}$ at $25^{\circ} \mathrm{C}$. In dilute acid, the Pu(V) and Pu(VI) will dissolve but the Pu(IV) hydrous oxide will not. In addition, the $\mathrm{Pu}(\mathrm{V})$ should not disproportionate significantly as it would with higher acid concentrations. Higher acid concentrations would be expected to dissolve the $\mathrm{Pu}$ (IV) hydroxide. A background electrolyte, $\mathrm{NaClO}_{4}$, was used in concentrations ranging from 0 to $1 \mathrm{M}$ to test the effect of ionic strength. The supernatant solutions were analyzed for total $\mathrm{Pu}$ concentration by $\alpha$ counting and absorption spectra could be gathered to identify oxidation states. 
Unfortunately, no valence measurements were presented. It was found that increased ionic strength in the mother solution ( 0 to $1 \mathrm{M} \mathrm{NaClO}_{4}$ ) generally decreased $\mathrm{Pu}$ dissolution for the lower acid concentrations $\left(0.1\right.$ and $\left.0.5 \mathrm{M} \mathrm{HClO}_{4}\right)$ but had negligible effect at $1 \mathrm{M}$ acid. Increasing dissolution time from 10 to 20 minutes increased dissolution in most instances. Increasing acid also increased dissolution, especially the increase from 0.5 to $1 \mathrm{M} \mathrm{HClO}_{4}$. It was found that the solids prepared in $1 \mathrm{M} \mathrm{NaOH}$ were somewhat more easily dissolved than those prepared in $5 \mathrm{M} \mathrm{NaOH}$.

The effects of $\mathrm{NaOH}$ concentration on the completeness of $\mathrm{Pu}$ dissolution were tested. The solids were prepared by 3 hours' aging at room temperature. The amount of solids dissolved generally increased with increasing $\mathrm{NaOH}$ concentration used in their preparation.

Dr. Tananaev concluded that solids leaching is an imperfect method to determine the solids properties. He would like to investigate methods based on spectrophotometry of solids but is apprehensive with this approach because of the contamination hazard to the instruments. He also mentioned his intent to prepare sodium double salts of the form $\mathrm{NaPu}(\mathrm{OH})_{5}$ or $\mathrm{Na}_{2} \mathrm{Pu}(\mathrm{OH})_{6}$ using hydrothermal techniques.

\subsubsection{Coprecipitation}

The program on the continuing development of coprecipitation of actinides from alkaline solution by the "Method of Appearing Reagents" (MAR) is being led by Dr. Alexander Bessonov of Professor Krot's group. Work on this topic commenced last year. In MAR, an alkali-soluble salt is converted by hydrolysis, chemical reduction, or decomposition to an insoluble precipitating agent. Because the precursor salt is distributed uniformly in the solution, the precipitation occurs homogeneously and efficient coprecipitation of actinides can transpire. Dr. Bessonov was in Germany during the program review. Therefore, the discussion was led by the laboratory head, Professor Krot. Also attending, though not actively discussing, were Drs. Tananaev, Gamov, Budantseva, Charushnikova, and Gelis.

The principal goal of the investigations conducted since the start of the contract on March 1, 1996 was to find a suitable reductant for $\mathrm{Np}(\mathrm{V})$ to prepare $\mathrm{Np}(\mathrm{IV})$ and thus enhance its coprecipitation. The second objective was to continue investigation of plutonium coprecipitation, only using $\mathrm{Pu}(\mathrm{IV})$ at about $5 \times 10^{-7} \mathrm{M}$ [rather than $\mathrm{Pu}(\mathrm{V})$ or (VI) at about $10^{-4} \mathrm{M}$ as used in previous tests]. It could be argued that the $\mathrm{Pu}$ in the earlier tests did not coprecipitate but merely precipitated without carrier as the low-solubility Pu(IV) hydrous oxide. The lower Pu concentration is at or below the Pu(IV) solubility limit established in tests by Prof. Peretrukhin and colleagues (1996). Therefore, any decrease in concentration in tests giving carrier precipitation should be attributable to coprecipitation. To detect the lower actinide concentrations, isotopes with higher specific activities were used: ${ }^{238} \mathrm{Pu}$, as a spike, and ${ }^{239} \mathrm{~Np}$, derived from alpha decay of ${ }^{243} \mathrm{Am}$.

Tests with Pu(IV) coprecipitation showed that decontamination factor (DF) increased as precipitating agent concentration increased (though not dramatically). The DFs decreased as 
hydroxide concentrations increased. Cobalt(III) hydrous oxide gave generally high DFs (100 to 800); better for the Co(III) hexaammine complex precursor than for the chloride pentaammine complex. As shown in the previous work, coprecipitations with manganese(IV) dioxide and Mn(II) hydroxide gave lower DFs than observed for most other coprecipitating agents. In all, these results are consonant with previous findings. Therefore, coprecipitation actually did occur in the earlier tests, not merely precipitation of the oversaturated [with respect to Pu(IV)] plutonium spike.

Neptunium(V) reduction and coprecipitation with $\mathrm{Cr}$ (III) hydroxide using $\mathrm{Cr}$ (III) acetate and nitrate salt precursors and hydrazine, dithionite, and vanadium(IV) $\left(\mathrm{VO}^{2+}\right)$ as neptunium reducing agents was also tested as a function of contact time, hydroxide concentration, coprecipitant concentration, and temperature. Initial neptunium concentration was $10^{-6} \mathbf{M}$, at or below the solubility of $\mathrm{Np}(\mathrm{IV})$ in $\mathrm{NaOH}$ solution. As expected, the DFs increased with time and coprecipitant concentration, and marginally with temperature. The DFs fell with increasing hydroxide concentration. Significantly, the V(IV) reductant was about five-times more effective at higher hydroxide concentrations than either the hydrazine or dithionite. The reasons for the better performance of vanadyl are not known but may be because both $\mathrm{V}(\mathrm{IV}) \rightarrow \mathrm{V}(\mathrm{V})$ and $\mathrm{Np}(\mathrm{V}) \rightarrow \mathrm{Np}$ (IV) are one-electron reactions. The potential of the $\mathrm{V}(\mathrm{IV}) / \mathrm{V}(\mathrm{V})$ couple $\left[\mathrm{VO}_{2}(\mathrm{OH})_{2}^{2-} / \mathrm{VO}_{4}^{3-}\right]$ is about -0.8 volts (Bratsch 1989).

Professor Shilov was asked about the reactions of nitrite $\left(\mathrm{NO}_{2}\right)$ with the actinides in alkali. The potential of the nitrite/nitrate couple is about 0.01 volts and should have small influence compared with air according to Prof. Shilov. However, no explicit experiments have been conducted. It was mentioned that some preliminary experiments were conducted in which the influence of aluminate on $\mathrm{Np}$ coprecipitation was studied. The aluminate was formed by the alkaline treatment of aluminum nitrate. The nitrate, and aluminate, were found to have no effect on the coprecipitation of neptunium with $\mathrm{Cr}$ (III) hydroxide; V(IV) was used as the Np reductant.

\subsubsection{Catalytic Organic Oxidation and Np(V) Reduction}

The task related to homo- and heterogeneous catalysis for the reduction of $N p(V)$ to $N p(I V)$ and the oxidation of tank waste organics in alkaline media is being conducted by Prof. Shilov of Prof. Krot's group. Because of Professor Shilov's limited English, Prof. Krot described the work. Also attending the discussions were Drs. Charushnikova and Garnov.

Tests on $\mathrm{Np}(\mathrm{V})$ reduction were described first. The initial studies investigated candidate reductants effective in alkaline solution. These investigations built on the work conducted last fiscal year by Prof. Shilov in which hydrazine was found to be the best reductant. Hydrazine hydrochloride was found to be not as effective as hydrazine hydronitrate. Heating is required to maximize the effectiveness. Catalysts tested were $\mathrm{Cu}(\mathrm{II}), \mathrm{Co}(\mathrm{II}), \mathrm{Ni}(\mathrm{II})$ (all at $10^{-4} \mathrm{M}$ ), and solid Pt and Pd metal. Effectiveness was poor for all tested catalysts. Charcoal also was tested as a possible catalyst and was effective but probably because of reduction by the charcoal itself, not any catalytic effect. Other charcoals may have better 
performance but desorption could be a problem and the distribution coefficients could be poor. Plans exist to study vanadyl sulfate $\left(\mathrm{VOSO}_{4}\right)$ with various catalysts. Formate may be investigated as a reductant but the reaction is expected to be slow.

Tests of oxidation of EDTA in $\mathrm{NaOH}$ solution with persulfate, hydrogen peroxide, hypochlorite, and hypobromite in the presence and absence of catalysts were described. Metal ion catalysts tested included $\mathrm{Fe}(\mathrm{III}), \mathrm{Co}(\mathrm{II}), \mathrm{Cu}$ (II), $\mathrm{Ni}(\mathrm{II}), \mathrm{Mn}(\mathrm{II}), \mathrm{Pb}$ (II), $\mathrm{Ag}$ (II) and others. The initial EDTA concentration was $0.02 \mathrm{M}$; EDTA decomposition was followed by complexometric titration with Th(IV) using xylenol orange indicator. Because initial decomposition products may themselves be chelating agents (e.g., ED3A, ethylenediaminetriacetate), this analytical technique actually measures loss of chelating strength. With $0.01 \mathrm{M}$ persulfate $\left(\mathrm{S}_{2} \mathrm{O}_{8}^{2-}\right)$, better results were obtained as $\mathrm{NaOH}$ concentration increased. Only Ag(II) catalyst improved reaction rates with persulfate.

Hydrogen peroxide in the absence of catalysts was tested in the interval 0.5 to $5 \mathrm{M} \mathrm{NaOH}$ and at 25 and $80^{\circ} \mathrm{C}$. No or negligible organic oxidation was observed under these onditions. The only catalyst found to be effective with peroxide was $\mathrm{Co}$ (II) at 60 to $80{ }^{\circ} \mathrm{C}$. Better results were obtained if the $\mathrm{H}_{2} \mathrm{O}_{2}$ was added stepwise (or continuously) rather than as a bolus. Reaction also was more extensive at lower $\mathrm{NaOH}$ concentration $(0.1 \mathrm{M})$. In later discussions, Professor Krot explained that autocatalytic decomposition of peroxide can occur if the peroxide concentrations are too large. About 3 to 5 moles of $\mathrm{H}_{2} \mathrm{O}_{2}$ were required per mole of EDTA; the rate increased with increasing $\mathrm{Co}(\mathrm{II})$ catalyst concentration.

Hypobromite $\left(\mathrm{BrO}^{-}\right)$decomposed EDTA effectively at room temperature without a catalyst. Hypobromite performed better if added stepwise because the unwanted disproportionation to bromide and bromate $\left(\mathrm{BrO}_{3}^{-}\right)$was minimized. Increasing temperature increased the rate of disproportionation but did not improve EDTA decomposition rate. Most catalysts were not effective with this oxidant; only $\mathrm{Cu}(\mathrm{II})$ and $\mathrm{Ni}(\mathrm{II})$ were somewhat effective. Low $(0.5 \mathrm{M})$ $\mathrm{NaOH}$ concentrations favored the reaction with hypobromite; at $5 \mathrm{M} \mathrm{NaOH}$, the rate and degree of reaction was low both in the presence and absence of catalysts.

Hypochlorite $\left(\mathrm{ClO}^{-}\right)$seems to behave like hypobromite, but more effectively, as determined from the scoping studies performed to date.

In addition to EDTA, HEDTA (N-2-hydroxyethyl ethylenediaminetriacetate) decomposition was being studied; initial results showed its behavior similar to that of EDTA. Citrate also was being studied with $\mathrm{H}_{2} \mathrm{O}_{2}$ and catalysts; decomposition was not observed. Citrate decomposed with persulfate. Tests with glycolate are planned but a different analytical technique must be used. Tests with oxalate may also be done but the solubility of sodium oxalate in $\mathrm{NaOH}$ solution is low and makes testing difficult to perform and assess. 


\subsubsection{Fission Product and Technetium Removal from Alkaline Media}

Professor Peretrukhin, head of the Laboratory on Radiochemical Investigations, is leading the task to study the removal of the fission product technetium, and other fission products (cesium, strontium), from alkaline solution. Initial work was aimed at the MAR. The conditions identified by Prof. Krot and his group in the work performed last fiscal year to remove $\mathrm{Np}(\mathrm{V}, \mathrm{VI})$ and $\mathrm{Pu}(\mathrm{V}, \mathrm{VI})$ from alkaline solution by homogeneous carrier precipitation were adopted. Dr. Tananaev presented these results. Not surprisingly, strontium was found to coprecipitate well with the carriers studied. The best results were found for sodium uranate coprecipitation using $\left[\mathrm{UO}_{2}\left(\mathrm{O}_{2}\right)_{3}\right]^{4-}$ as precursor. Unfortunately, but also as expected, cesium coprecipitation under MAR was poor in all cases studied.

A modified coprecipitation technique was tested that combined two of the precipitant precursors studied in Prof. Krot's MAR work to produce the coprecipitating carrier. The alkali-soluble complexes were nitroprusside [introduced as $\mathrm{Na}_{2} \mathrm{Fe}(\mathrm{CN})_{5} \mathrm{NO}$ ] and cobalt(III) pentaammine [added as $\mathrm{Co}\left(\mathrm{NH}_{3}\right)_{5} \mathrm{Cl}_{3}$ ] or cobalt(III) hexaammine [added as $\mathrm{Co}\left(\mathrm{NH}_{3}\right)_{6} \mathrm{Cl}_{3}$ ]. The precipitate product appears to be analogous to the nickel ferrocyanide used previously at the Hanford Site. Cesium DFs around 20 to 60 (for the pentaammine) and 300 (for the hexaammine), were obtained at 0.01 to $0.04 \mathrm{M} \mathrm{NaOH}$. However, these DFs were decreased sharply to about 5 as ionic strength increased to about $0.5 \mathrm{M}$ using $\mathrm{NaNO}_{3}$. Cesium therefore does not seem amenable to coprecipitation by the MAR. Further work is planned to investigate the effects of simulant wastes composition and precipitate washing on decontamination.

Dr. V. I. Silin then discussed his findings on the removal of pertechnetate from alkaline solution by the MAR. A priori, it was expected that coprecipitation would not be successful unless the pertechnetate were chemically reduced to the (V) or (IV) oxidation state. The experiments confirmed this behavior. There is some speculation that the form of $\mathrm{Tc}(\mathrm{V})$ is analogous with that of $\mathrm{Np}(\mathrm{V})$ in alkaline solution; i.e., that it is present as an anionic hydroxide complex. Tests are planned using the $\left[\mathrm{UO}_{2}\left(\mathrm{O}_{2}\right)_{3}\right]^{4-}$ complex as the precipitate precursor for sodium uranate. However, the IPC/RAS scientists are not optimistic because the peroxide will keep the technetium oxidized and in the form of pertechnetate.

Because the prospects of Tc(VII) coprecipitation by the MAR are poor, Prof. Peretrukhin and Dr. Silin are investigating other methods for the removal of pertechnetate from alkaline solution. Prof. Peretrukhin's attendance of the Tank Waste Symposium at the American Chemical Society (ACS) national meeting in New Orleans in March 1996, and his review of the recent reports on sorption research conducted by S. Frederick Marsh and Z. Svitra of Sandia and Los Alamos National Laboratories, respectively, made him realize that solvent extraction and sorption techniques are being vigorously investigated in the United States. Therefore, he decided to examine electroless plating (also called contact reduction on an active metal, or cementation) as a technetium removal approach.

In electroless plating, a metal with oxidation potential lower than the reduction potential of pertechnetate is contacted with the pertechnetate-bearing solution. The pertechnetate 
chemically reduces to the less soluble $\mathrm{Tc}(\mathrm{IV})$ or $\mathrm{Tc}(\mathrm{V})$ hydrous oxide and deposits on the active metal surface. The technetium can be removed from the metal surface by oxidation to Tc(VII) with peroxide.

Dr. Silin described the tests he performed. Initial tests used three metals: tin, lead, and a lead:tin mixture in a 2:1 ratio (also containing 2 weight percent antimony). This seemingly odd mixture has a commonplace source -- it is bird shot. In static tests (non-flowing solution in contact with the metal), the best technetium removal was about $40 \%$ (a DF of about 2). With a column of metal pieces in solution flow conditions, DFs of about 3 were obtained. In tests with simulant waste, chromate unfortunately also was reduced to $\mathrm{Cr}$ (III) and thus would report, with the technetium, to the high-level fraction.

Static tests conducted by Alexei Kareta, a PhD student in Prof. Peretrukhin's group, with flat metallic chromium pieces showed promising results. Further tests with chromium metal shot are desired but the shot material form was not available to the IPC/RAS. Chromium shot is being provided to the IPC/RAS by the liaison.

Further discussion on electroless plating took place. Use of an applied electrical potential to help the deposition of technetium was considered. The merits and constraints of this approach, and the attractiveness of separated and non-separated electrochemical cells, were addressed.

Based on this dialogue, other tests will be conducted in which electrical potential will be applied on the metal to effect reduction. Both separated and non-separated cells will be tried. According to Prof. Peretrukhin, anion exchange membrane would be ideal to use in separated cells. The membrane should have the following characteristics: stable in $\mathrm{NaOH}$ solution, stable to higher aqueous temperatures, low electrical resistance, high working hours/days rating, and a closed cylinder form.

\subsection{PROPOSED FUTURE IPC/RAS TASKS}

During the program review at the IPC/RAS in June 1996, two proposed areas of work for FY 1997 were discussed. One proposal was made by the liaison to investigate the behavior of plutonium (co)precipitates at Hanford Site tank waste sludge conditions. The second proposal, offered by the IPC/RAS, involved application of chitin sorbents to removal of transuranics from alkaline solution. A third task, the preparation of a literature review on USSR/Russian experience in crystallization of sodium nitrate from radioactive waste, also was discussed. The review would be provided prior to the end of FY 1996. 


\subsubsection{Plutonium Precipitates in Sludge}

The disposition of plutonium in Hanford Site tank waste sludge is of concern in waste storage and processing operations. Nuclear material criticality is of concern if hydraulic or solubility forces cause redistribution of plutonium to relatively compact geometries and high concentrations (greater than 2.6 grams per liter). Central to understanding plutonium behavior is determining whether the plutonium, present as $\mathrm{Pu}(\mathrm{IV})$, is incorporated chemically in the bulk sludge matrix (with neutron absorbers like bismuth or lanthanum or with non-absorbers like nuclear-grade zirconium) or recrystallizes as a separate $\mathrm{PuO}_{2} \cdot \mathrm{xH}_{2} \mathrm{O}$ phase.

An outline of a laboratory program to investigate the distribution of plutonium under sludge-forming conditions was prepared in April 1996 by the liaison for consideration of the IPC/RAS scientists. Factors to be investigated include:

- Alkalinity (pH/OH')

- Presence/absence of carbonate

- Redox control through the presence/absence of nitrite

- Presence/absence of coprecipitating waste components [for example, Fe(III), $\mathrm{Al}(\mathrm{III}), \mathrm{Zr}(\mathrm{IV}), \mathrm{La}(\mathrm{III}), \mathrm{Bi}(\mathrm{III}), \mathrm{Cr}(\mathrm{III})$, silica, phosphate]

- Plutonium sorption on metal (hydr)oxides

- $\quad$ Time

- Temperature.

Professor Krot replied to the outlined program with an experimental approach to study the condition of plutonium in Hanford-type sludges. Physical measurements of particle settling rates, examination of sludge solids (by microscopy, X-ray diffractometry, infrared spectrometry, dissolution in mineral acids), and analysis of solution concentrations are included in the proposed experiments. Further elaboration of this outlined work for DOE support in FY 1997 is planned.

\subsubsection{Actinide Sorption from Alkali on Chitins}

Professor B. G. Ershov, head of the Laboratory of Radiation-Chemical Transformation of the IPC/RAS, prepared and discussed a proposal for investigating actinide sorption from alkaline solution on chitin-containing materials. Also present during this discussion were Professor Krot and Dr. Tananaev. Chitin is derived from the exoskeletons of marine arthropods (e.g., shrimp, lobster, crab). Professor Ershov described the chemical form of 
chitin (poly $\mathrm{N}$-acetyl glycosamine) in analogy with the polysaccharide cellulose. Chitin is a cellulose structure in which a cellulosic $-\mathrm{OH}$ group is replaced by a $-\mathrm{NHCOCH}_{3}$ group. Strong alkaline hydrolysis of chitin in $40 \% \mathrm{NaOH}$ at 150 to $180^{\circ} \mathrm{C}$ cleaves acetate and leaves the $-\mathrm{NH}_{2}$ group; this compound is called chitosan. Both chitin and chitosan are resistant to high alkali concentrations at moderate temperatures and thus are stable to Hanford Site tank waste media; both are insoluble in water and inorganic solvents.

Chitin and chitosan exhibit strong sorptive properties for transition metals and transuranium elements. In scoping tests (performed by Dr. Tananaev) using sorbent/solution ratios of 1 gram solid per $200 \mathrm{~mL}$ solution, $\mathrm{K}_{d} \mathrm{~s}$ (= concentration on solid phase, per gram, divided by the concentration in solution, per milliliter) of about 7000 to $10,000 \mathrm{~mL} / \mathrm{g}$ were observed for u(IV) up to $4 \mathrm{M} \mathrm{NaOH}$. For $\mathrm{Np}(\mathrm{V}), \mathrm{K}_{d}$ s of 4000 to 9000 were observed at 0.12 to $1.9 \mathrm{M}$ $\mathrm{NaOH}$; the $\mathrm{K}_{d}$ decreases to about $1000 \mathrm{~mL} / \mathrm{g}$ at $4 \mathrm{M} \mathrm{NaOH}$. Stripping can be accomplished by acetic acid at about pH 2 .

These are very favorable $\mathrm{K}_{\mathrm{d}} \mathrm{s}$, especially for $\mathrm{Np}(\mathrm{V})$. Professor Ershov proposed that work in this area be supported by the DOE. The work would occur jointly in Professor Ershov's and Krot's groups. Aspects of the proposed work to be considered are kinetics, effects of waste components, actinide oxidation states, column operation, stripping and washing, stability, selection of the optimum chitin/chitosan sorbent, and hydrodynamics. Further definition of proposed IPC/RAS work in this area for FY 1997 is planned.

\subsubsection{Literature Review: Sodium Nitrate from Radioactive Waste}

Crystallization of pure sodium nitrate $\left(\mathrm{NaNO}_{3}\right)$ from Hanford Site tank wastes has been demonstrated on a laboratory scale in work supported by the ESP (Herting 1996).

Substantial decontamination of the salt from radionuclides (primarily ${ }^{137} \mathrm{Cs}$ ) occurs by the acid-side recrystallization. The clean low-specific-activity material can itself be a waste form or can be put to beneficial use in radioactive or, with favorable regulatory ruling, non-radioactive applications. By this process, the amount of Hanford Site low-activity waste glass may be decreased by $90 \%$.

Investigations on the recovery of sodium nitrate from radioactive waste were conducted in the former Soviet Union. The preparation of a technical literature review by the IPC/RAS on these formerly classified unpublished studies was proposed in discussions between the liaison and IPC/RAS scientists during the visits in the United States and Russia. The task was outlined in correspondence between Dr. Daniel Herting and Cal Delegard with the IPC/RAS. The contract for the task was prepared by Dr. Albert; contract funding was $\$ 10,000$. A condensed version of the draft literature review was delivered by FAX on September 10, 1996; the complete draft version was delivered at the end of the FY 1996. Professor A. K. Pikaev, Dr. V. B. Kraphukin, and E. P. Krasavina are the primary authors. 


\subsection{TECHNICAL LITERATURE AND INFORMATION}

A number of technical reports (generally from DOE contractors) were provided to the IPC/RAS to communicate the status of research in the DOE technical community, to provide the composition and properties of Hanford Site tank waste, and to supply information on waste processing plans. The reports furnished to the IPC/RAS in FY 1996 are listed.

- Ashby, E. C., E. K. Barefield, C. L. Liotta, H. M. Neumann, F. Doctorovich, A. Konda, K. Zhang, J. Hurley, D. Boatright, A. Annis, G. Pansino, M. Dawson, and M. Juliao, "Mechanistic Studies Related to the Thermal Chemistry of Simulated Nuclear Wastes That Mimic the Contents of a Hanford Site Double-Shell Tank," pp. 249-284 in Emerging Technologies in Hazardous Waste Management IV, D. W. Tedder and F. G. Pohland, editors, American Chemical Society, Washington, D.C. (1994).

- Marsh, S. F., Z. V. Svitra, and S. M. Bowen, "Effects of Soluble Organic Complexants and Their Degradation Products on the Removal of Selected Radionuclides from High-Level Waste," LA-13000, Los Alamos National Laboratory, Los Alamos, New Mexico (1995).

- Karraker, D. G., "Solubility of Plutonium in Waste Evaporation," WSRC-TR-93-578, Rev. 0, Savannah River Technology Center, Aiken, South Carolina (1993).

- Hobbs, D. T. and D. G. Karraker, "Recent Results on the Solubility of Uranium and Plutonium in Savannah River Site Waste Supernate," WSRC-MS-94-061, Savannah River Technology Center, Aiken, South Carolina (1994).

- Karraker, D. G., "Uranium Solubility Studies During Waste Evaporation," WSRC-TR-93-433, Savannah River Technology Center, Aiken, South Carolina (1993).

- Karraker, D. G., "Solubility of Neptunium in Alkaline High-Level Waste (U)," WSRC-TR-94-0526, Rev. 1, Savannah River Technology Center, Aiken, South Carolina (1994).

- Worl, L. A., S. M. Bowen, J. M. Berg, D. D. Padilla, and M. R. Cisneros, "Actinide Removal from Hanford Supernatant Tank Waste," LA-UR-95-3743, Los Alamos National Laboratory, Los Alamos, New Mexico (1995).

- Delegard, C. H., "Calcination/Dissolution Chemistry Development Fiscal Year 1995," WHC-EP-0882, Westinghouse Hanford Company, Richland, Washington (1995). 
- Delegard, C. H., "Calcination-Dissolution Treatment of Hanford Site Tank Waste," WHC-SA-2911, Westinghouse Hanford Company, Richland, Washington (1996).

- Camaioni, D. M., W. D. Samuels, S. A. Clauss, B. D. Lenihan, K. L. Wahl, J. A. Campbell, and W. J. Shaw, "FY 95 Waste Aging Studies," PNL-10794, Pacific Northwest Laboratory, Richland, Washington (1995).

- Samuels, W. D., D. M. Camaioni, S. A. Clauss, J. C. Linehan, K. L. Wahl, B. D. Lenihan, and W. J. Shaw, "Investigation into the Chemical, Thermal, and Radiological Changes of Organic Chemicals Added to the Underground Storage Tanks at Hanford," PNL-SA-23331, Pacific Northwest Laboratory, Richland, Washington (1996).

- Delegard, C. H., "Liaison Activities with the Institute of Physical Chemistry of the Russian Academy of Sciences: Midyear Report," WHC-SP-1184, Westinghouse Hanford Company, Richland, Washington (1996).

- Fletcher, P. A., C. P. Jones, A. R. Junkison, R. I. Taylor, A. D. Turner, and P. R. Kavanagh, "Technetium Removal from Aqueous Wastes," DOE-HMIP-RR-92.053, Harwell Laboratory, Didcot, Oxfordshire, United Kingdom (1992).

- Hobbs, D. T., and D. G. Karraker, "Recent Results on the Solubility of Uranium and Plutonium in Savannah River Site Waste Supernate," Nuclear Technology, 114, pp. 318-324 (1996).

The following reports were provided by the reports' author to Professors Peretrukhin, Krot, Shilov, and Pikaev during their visit to the Savannah River Technical Center (SRTC) on March 29, 1996.

- Karraker, D. G., "Plutonium(VI) Solubility Studies in Savannah River Site High-Level Waste Supernate," WSRC-TR-95-0244, Savannah River Technology Center, Aiken, South Carolina (1995).

- Karraker, D. G., "Studies on SRS Waste Tank Supernate Solutions," WSRC-TR-96-4071, Savannah River Technology Center, Aiken, South Carolina (1996).

During the visit to Russia, it was discovered that decreasing Academy of Science funding forced IPC/RAS cancellation of subscriptions to important scientific journals (for example, Radiochimica Acta and Journal of Radioanalytical and Nuclear Chemistry Articles and Letters). The most recent issues of these two important journals were from 1993 . The liaison has purchased the missing back issues and a subscription to Radiochimica Acta for 1997. Purchase of the other journal is being investigated. 


\subsection{IPC/RAS SCIENTISTS' VISIT TO THE UNITED STATES}

Technical information on the Hanford Site, Savannah River Site, and Oak Ridge National Laboratory tank wastes was given to Professors Peretrukhin, Krot, Shilov, and Pikaev of the IPC/RAS during their liaison-funded visit to the United States in March and April 1996.

Technical information on the DOE Site tank waste systems and tank chemistries was obtained at the "Tank Waste Chemistry" symposium sponsored by the Industrial and Engineering Division of the American Chemical Society (ACS) at the ACS $211^{\text {th }}$ national meeting, March 24 to 28, 1996. The scientists met a number of DOE and DOE contractor technical personnel during this meeting, attended the 26 oral presentations, and viewed the 19 poster presentations. The IPC/RAS scientists also attended papers in the symposium "Centennial of the Discovery of Radioactivity."

The scientists learned of Savannah River Site tank waste properties from Dr. David Hobbs during a meeting at the SRTC. Dr. David Karraker, also of SRTC, presented an overview of his studies on the solubility of actinides (uranium, neptunium, and plutonium) in alkaline media simulating the Savannah River Site tank wastes. Unfortunately, a canceled flight decreased the planned day-long visit at the SRTC to four hours. Drs. Hobbs and Karraker graciously extended their Friday work day until well after 9:00 P.M. to host this visit.

The scientists also visited the Hanford Site April 1 to 3, 1996. A road tour of the Site on April 1 was led by Steve Buckingham, a retired chemist with over 40 years experience at Hanford. A visit to the Plutonium-Uranium Extraction plant also took place, with presentations by Don Harlow, a highly experienced plant engineer. The day ended with a visit to the 222-S Laboratory given by Dr. James $R$. Jewett, manager of the Process Chemistry and Statistics group of the Westinghouse Hanford Company. The analytical and process development facilities available at the 222-S Laboratory were shown during the tour.

A brief technical review and discussion of the IPC/RAS program for FY 1995 and 1996 was conducted on April 2 by Dr. Jack Watson, Dr. Kurt Gerdes (Program Coordinator, DOE-Headquarters), Cal Delegard, and the four IPC/RAS scientists. Subsequent individual discussions with Hanford Site scientists and engineers occurred on April 3.

\subsection{EQUTPMENT AND MATERIALS PROVIDED TO THE IPC/RAS}

An LSC was selected, procured, and delivered to the IPC/RAS to detect and quantify, separately and simultaneously, the concentrations of beta- and alpha-emitting radionuclides (for example, ${ }^{99} \mathrm{Tc}$, and ${ }^{237} \mathrm{~Np}$, ${ }^{239} \mathrm{Pu}$, and ${ }^{241} \mathrm{Am}$, respectively). A capital budget of $\$ 50,000$ was provided the liaison to accomplish the procurement.

With an LSC, more accurate analytical results and lower detection limits could be obtained for the DOE-funded studies. Without the LSC, cumbersome and error-inducing steps (neutralization, carrier precipitation, and acid dissolution) are required prior to preparation of 
classic planchet mounts. These steps are required to separate actinides and technetium from the high sodium salt matrices implicit in Hanford Site tank waste experiments. With an LSC, no separations are required prior to simple introduction of aliquots of the test solutions into the scintillation cocktail for counting in the LSC. The LSC also has increased sensitivity which reduces the detection limit. Enhanced sensitivity is especially important for studies of ${ }^{99} \mathrm{Tc}$ and ${ }^{237} \mathrm{~Np}$ which have low specific activities.

A market survey of suitable LSC instruments was conducted. The following criteria were considered in choosing the LSC:

- Simultaneous quantitation of alpha and beta radionuclides

- Instrument operation on $220 \mathrm{~V} / 50 \mathrm{~Hz}$ power

- Instrument delivery and installation at the IPC/RAS

- Training on use of the instrument in Russia; preferably in Moscow

- Established vendor sales and service office in Russia; preferably in Moscow.

Three candidate LSC devices met the stated criteria: the Model 1415-001 DSA ${ }^{\mathrm{m}}$ by Wallac $\mathrm{Oy}^{2}$ (about $\$ 52,000$ ), the LSA Model 2700TR ${ }^{\mathrm{Tm}}$ by Packard ${ }^{3}$ (about $\$ 52,000$ ), and the LS6500LL $L^{\mathrm{m}}$ by Beckman (about $\$ 32,000$ ). Wallac Oy also offered a more sensitive instrument at about $\$ 80,000$.

The performance characteristics of the candidate LSCs were assessed. The figure of merit in determining LSC performance is the counting efficiency squared divided by the associated background count rate. All instruments had equivalent figures of merit. The deciding factor then became price; on this basis, the Beckman LSC was selected. The Beckman LSC was delivered and installed at the IPC/RAS in February 1996. It is functioning well according to IPC/RAS scientists and was observed in action during the program review visit in June 1996. By use of the new LSC, the Np(IV) solubility studies were extended to $\mathrm{NaOH}$ concentrations below $2 \mathrm{M}$ where neptunium solution concentrations were below $10^{-6} \mathrm{M}$ ( 6 Becquerel $/ \mathrm{mL}$ ).

${ }^{2} 1415-001$ DSA is a trademark of Wallac Oy, Turku, Finland, an associate of EG\&G Company, Gaithersburg, Maryland.

${ }^{3}$ LSA Model 2700TR is a trademark of Packard, a Canberra Company, Meriden, Connecticut.

${ }^{4}$ LS6500LL is a trademark of Beckman Instruments, Brea, California. 
Some small equipment items and materials also were provided the IPC/RAS through the liaison. Ultrafilters (Model CF25", manufactured by Amicon ${ }^{5}$ ) were supplied to the IPC/RAS for use in solid-liquid separations in solubility and other tests. These filters have a nominal $1.8 \mathrm{~nm}$ pore size. Two Brinkmann ${ }^{6}$ adjustable pipets (100 and $1000 \mu \mathrm{L}$ capacity) and several hundred disposable pipet tips were supplied. Liquid scintillation cocktail having high capacity for dissolved salts (Ready-Gel, manufactured by Beckman ${ }^{7}$ ) was provided. Some electrode materials (chromium shot, graphite chips, and some fabricated graphite pieces) for technetium electro- and electroless-deposition were provided.

${ }^{5} \mathrm{CF} 25$ is a trademark of Amicon, Inc., Beverly, Massachusetts.

${ }^{6}$ Brinkmann Instruments, Inc., Westbury, New York.

${ }^{7}$ Ready-Gel is a trademark of Beckman Instruments, Brea, California. 


\subsection{DISSEMINATION SUBTASK}

The dissemination subtask included presentation of IPC/RAS findings to technical personnel in the DOE community and publication of IPC/RAS reports as Westinghouse Hanford Company documents.

\subsection{PRESENTATIONS}

Technical presentations on the IPC/RAS FY 1995 tasks were made by the IPC/RAS scientists in scientific colloquia at the ACS national meeting, the SRTC, and at the Hanford Site. The IPC/RAS liaison task supported the travel and living expenses of the four scientists to the United States.

The $211^{\text {th }}$ National Meeting of the ACS took place March 24 to 28, 1996 in New Orleans, Louisiana. The following IPC/RAS papers were presented at the ACS Division of Industrial and Engineering Chemistry symposium, "Tank Waste Chemistry:"

- $\quad$ "Study of Some Redox Reactions of Neptunium and Plutonium for the Stabilization of Particular Oxidations States in Alkaline Media" by V. P. Shilov, N. N. Krot, A. Yusov, A. Garnov, and V. Perminov

- $\quad$ Gamma Radiolysis of Alkaline Aqueous Solutions of Neptunium and Plutonium" by A. K. Pikaev and A. V. Gogolev

- $\quad$ "Coprecipitation of $\mathrm{Np}(\mathrm{VI}, \mathrm{V})$ and Pu(VI,V) from Alkaline Solutions with Some Carriers Formed by the Method of Appearing Reagents" by N. N. Krot, V. P. Shilov, A. Bessonov, N. Budantseva, I. Charushnikova, and V. Perminov.

- $\quad$ "Solubility of Transuranium Elements and Technetium Hydroxide Compounds in $\mathrm{NaOH}$ Solutions in the Presence of Redox and Complexing Agents" V. F. Peretroukhin, I. G. Tananaev, S. V. Kryutchkov, V. I. Silin, and C. H. Delegard (Peretroukhin et al. 1995)

All papers were presented orally except the radiolysis report which was presented as a poster. In addition, "Calcination/Dissolution Treatment of Hanford Site Tank Waste" by C. H. Delegard (1996), which reported work supported by ESP in previous years, was presented orally.

The four IPC/RAS scientists presented their papers in a roundtable session at the SRTC on March 29, 1996. Dr. David Hobbs, Dr. David Karraker, and two other SRTC persons attended. 
Finally, the four IPC/RAS scientists presented their work in a sitewide "Hanford Technical Exchange" on April 2, 1996. The following talks also were given at the Exchange:

- $\quad$ "Scientific Activity of the Institute of Physical Chemistry," by A. K. Pikaev of the IPC/RAS

- "Thermodynamic Modeling of the Solubility of $\mathrm{PuO}_{2} \cdot \mathrm{xH}_{2} \mathrm{O}(\mathrm{am})$ in Alkaline Hanford Waste Solutions," by Linfeng Rao of the Pacific Northwest National Laboratory

- "The Solubility and Aqueous Thermodynamics of Tetravalent Actinides in Concentrated Carbonate Solutions," by Andrew Felmy of the Pacific Northwest National Laboratory.

\subsection{PUBlications}

Reports on the work performed by the IPC/RAS in FY 1995 were prepared and issued, without editing, to a limited distribution of DOE and contractor personnel by Thomas $\mathrm{E}$. Albert and Associates in the autumn/winter of 1995 and spring of 1996 . As part of the liaison task, these reports were technically reviewed, formatted, edited, and issued (after rechecking by the authors) as publicly-available Westinghouse Hanford Company documents.

The following reports have been issued:

- Investigation of Some Redox Reactions of Neptunium, Plutonium, Americium, and Technetium in Alkaline Media" (Shilov et al. 1996)

- "Investigation on the Coprecipitation of Transuranium Elements from Alkaline Solutions by the Method of Appearing Reagents" (Krot et al. 1996)

- $\quad$ "Radiolysis of Actinides and Technetium in Alkaline Media" (Pikaev et al. 1996)

- "Determination of the Solubility of Np(IV-VI), Pu(III-VI), Am(III-VI), and Tc(IV, V) Hydroxo Compounds in 0.5 to $14 \mathrm{M} \mathrm{NaOH}$ Solutions" (Peretrukhin et al. 1996).

\subsection{PATENT}

A potentially patentable invention was discovered by Professor Nikolai N. Krot and his colleague, Dr. Iraida A. Charushnikova, in their work on the coprecipitation task. The invention has been described in an Application for United States Letters Patent, number S-86-247 titled, "Removal of Dissolved Actinides from Alkaline Solutions by the 
Method of Appearing Reagents." The Application was prepared by Mr. Harry Levi of Emrich and Dithmar, 300 South Wacker Drive, Chicago, Illinois. The firm was engaged by Ms. Rebecca Keen of SAIC, 555 Quince Orchard Road, Suite 500, Gaithersburg, Maryland. The liaison provided assistance in the preparation of the technical details of the Application. 
This page intentionally left blank. 


\subsection{VERIFICATION SUBTASK}

Verifications of the findings obtained by the IPC/RAS scientists in their FY 1995 redox reagent/reaction, solubility, coprecipitation, and radiation chemistry tasks were undertaken by comparing their results with published results from independent laboratories and with previously unpublished results obtained in the author's laboratory. The results of these comparisons are presented in this section. Investigating the attainment of equilibrium in tests involving the slowly crystallizing Pu(IV) hydrous oxide phase also was a part of this task.

\subsection{ATTAINING EQUILIBRIUM}

Attaining equilibrium in solubility tests of slowly-crystallizing plutonium(IV) hydrous oxide in strongly alkaline solution is difficult, if not impossible. Previous studies have shown equilibrium, or even steady-state plutonium concentrations, are not obtained even after almost three-years aging (Delegard 1985). The following data, obtained by precipitating $\mathrm{Pu}$ (IV) (introduced as acidic nitrate solution) in $5 \mathrm{M} \mathrm{NaOH}$ solution held in polyethylene vessels, support this conclusion. Results from three separate solubility experiments were consistent; plutonium concentrations rose about a factor of 10 in aging from one hour to one week, then decreased a factor of 10 in further aging to almost three years (see Figure 6-1).

These results indicate that, at least for Pu(IV) hydrous oxide, establishing "equilibrium" does ot occur in short-term experiments. Therefore, care must be taken in analyzing or interpreting solubility investigations or in any tests in which Pu(IV) hydrous oxide participates.

Figure 6-1. Solubility Variation with Aging of $\mathrm{PuO}_{2} \cdot \mathrm{xH}_{2} \mathrm{O}$ in $5 \mathrm{M} \mathrm{NaOH}$.

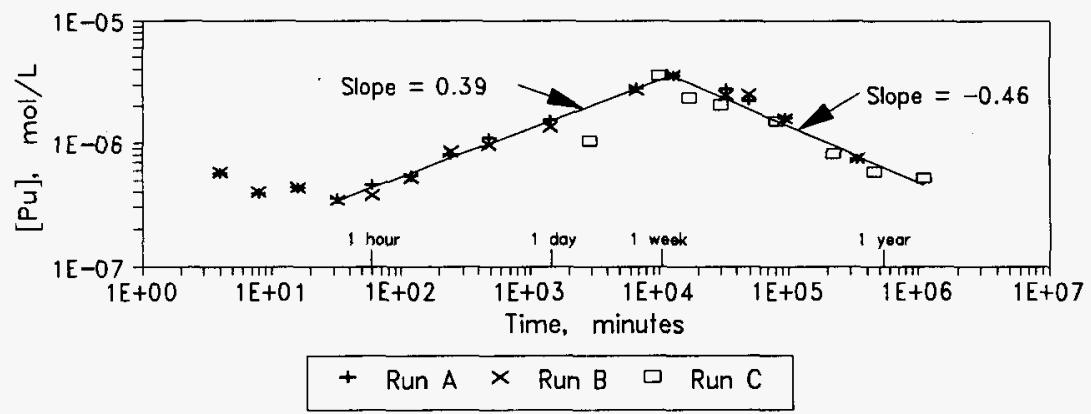




\subsection{SOLUBILITY}

The solubilities of the actinides ( $\mathrm{Np}, \mathrm{Pu}$, and $\mathrm{Am})$ and technetium in various oxidation states over a range of sodium hydroxide concentrations were investigated by Peretrukhin et al. (1996). Results from the solubility studies for the actinides may be compared with results obtained in other laboratories using similar solution compositions.

\subsubsection{Neptunium(V)}

The solubility of sodium neptunate(V) salts in varying concentrations of $\mathrm{NaOH}$ was reported (Peretrukhin et al. 1996). The solution concentrations obtained by the IPC/RAS for analogous plutonium and americium systems are similar (except for plutonium at low $\mathrm{NaOH}$ concentrations) and indicate similar solid phases and solution species. The IPC/RAS results can be compared with data recently published (Karraker 1994b and Delegard 1995a) as shown in Figure 6-2.

In the IPC/RAS tests, the neptunium concentrations rise smoothly about a factor of five by increasing $\mathrm{NaOH}$ concentrations from 0.5 to $17.5 \mathrm{M}$ and was attributed to the formation of $\mathrm{Np}(\mathrm{V})$ hydroxide complexes. Studies by Karraker (1994b) on neptunium(V) salt solubility in simple $\mathrm{NaOH}$ solutions, in $\mathrm{NaOH}$ solutions containing $\mathrm{NaNO}_{3}$ and $\mathrm{NaNO}_{2}$, and in Savannah River Site simulant waste solutions during evaporative concentration, are generally within a factor of two of the values found by the IPC/RAS scientists. Karraker (1994b) also reported that $\mathrm{Np}(\mathrm{IV})$ and $\mathrm{Np}(\mathrm{VI})$ converted to $\mathrm{Np}(\mathrm{V})$ in a few days in the synthetic waste solutions studied; that is, $\mathbf{N p}(\mathrm{V})$ seems to be the stable oxidation state in aerated strongly alkaline solution.

The single data point from Delegard (1995) reflects $\mathrm{Np}(\mathrm{V})$ concentrations found in a solution prepared from calcination and water dissolution of a neptunium-spiked Hanford Site simulant waste. The solution species was identified as $\mathrm{Np}(\mathrm{V})$ by absorption spectrophotometry. The $\mathrm{Np}(\mathrm{V})$ solution concentration found in the single test was very near the concentration expected from the IPC/RAS studies.

\subsubsection{Plutonium(IV)}

The solubility of plutonium(IV) hydrous oxide in the presence of $0.1 \mathrm{M}$ hydrazine holding reductant was determined by the IPC/RAS after 72 hours' equilibration time (Peretrukhin et al. 1996). Confirmation that the solution phase plutonium was tetravalent was not performed because conventional spectrophotometry is almost impossible at the low concentrations involved, and because valence tests on the acid side would be compromised by the residual hydrazine. 
Figure 6-2. Solubility of $\mathrm{Np}(\mathrm{V})$ Salts in $\mathrm{NaOH}$ Solutions.

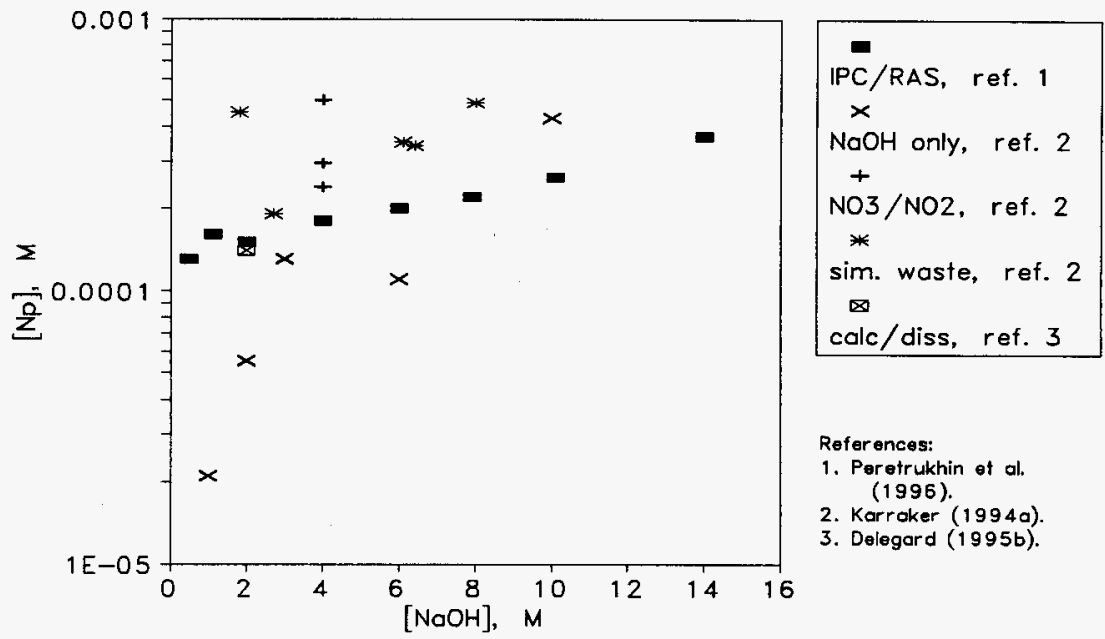

Previously unpublished studies performed by the author were conducted at similar conditions ( $0.05 \mathrm{M}$ hydrazine and 48 hours contact time). The data from these two studies are compared in Figure 6-3. The two sets of data agree well over the entire $\mathrm{NaOH}$ concentration range except for one pair of data points above $14 \mathrm{M} \mathrm{NaOH}$. In that case, the $0.05 \mathrm{M}$ hydrazine in the author's studies may have been depleted, allowing the plutonium(IV) solids to air-oxidize and dissolve as Pu(V).

The plutonium concentrations observed in aerated $\mathrm{NaOH}$ solutions in the absence of hydrazine after two days contact are also shown in Figure 6-3. The difference between plutonium concentrations in the presence and absence of hydrazine is negligible below about $6 \mathrm{M} \mathrm{NaOH}$. Above $6 \mathrm{M} \mathrm{NaOH}$, hydrazine decreases plutonium concentration, presumably by preventing plutonium(IV) hydrous oxide from oxidizing and dissolving. 
Figure 6-3. Solubility of $\mathrm{Pu}(\mathrm{IV})$ Hydrous Oxide in $\mathrm{NaOH}$ Solutions.

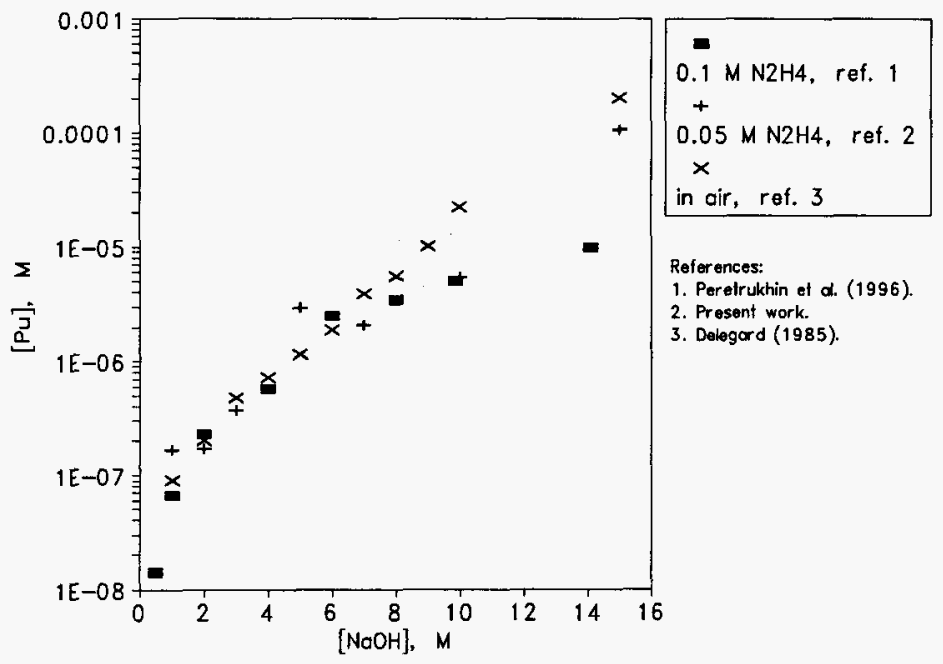

In light of the postulated $\mathrm{Pu}(\mathrm{IV}) \rightarrow \mathrm{Pu}(\mathrm{V})$ oxidative dissolution reaction, the absence of an effect for hydrazine is unexpected. This observation could be taken as evidence that oxidative dissolution does not occur at lower hydroxide concentrations; that is, the plutonium dissolved species is $\mathrm{Pu}(\mathrm{IV})$ below $6 \mathrm{M} \mathrm{NaOH}$. Hydrazine has been observed to reduce $\mathrm{Pu}(\mathrm{V})$ in alkaline media effectively at lower $(<6 \mathrm{M})$ alkali concentrations (Shilov et al. 1996). These observations are consistent with those of Dr. Tananaev who found that Pu(V) is reduced readily by hydrazine to form green precipitates ${ }^{8}$ leaving $10^{-6}$ to $10^{-7} \mathrm{M}$ dissolved plutonium (see Section 4.2.1). Further work on determining the stability of Pu(V) in alkaline media is occurring in FY 1996.

${ }^{8}$ Plutonium(IV) hydrous oxide is green; Pu(V) sodium salts are grey (Peretrukhin et al. 1996). 


\subsubsection{Plutonium(V)}

The solubility of $\mathrm{Pu}(\mathrm{V})$ sodium salts in solutions ranging from 0.6 to $14 \mathrm{M} \mathrm{NaOH}$ was studied by Peretrukhin et al. (1996) and is shown in Figure 6-4. The observed plutonium concentrations increased about seven-fold over this range and were slightly lower than observed for neptunium(V) under comparable conditions above about $6 \mathrm{M} \mathrm{NaOH}$. Below 6 $\mathrm{M} \mathrm{NaOH}$, the plutonium concentrations are as much as two-fold lower than those observed for $\mathrm{Np}(\mathrm{V})$. The IPC/RAS scientists ascribed this behavior to the disproportionation and the instability of the sodium plutonate(V) salt.

Two independent data points provisionally support the Pu(V) solubility results. Both points were observed in calcined and dissolved Hanford Site tank waste. One test used a simulant waste, and the plutonium solution species was identified as $\mathrm{Pu}(\mathrm{V})$ by spectrophotometry; the other test was run under similar calcination/dissolution conditions with a genuine waste from tank 241-SY-101. Spectrophotometric confirmation of the plutonium species was not possible for the genuine tank waste because of intense coloration by manganate.

\subsubsection{Plutonium(VI)}

The solubilities of plutonium(VI) sodium salts in $\mathrm{NaOH}$ solutions were not determined explicitly by IPC/RAS studies. However, information was obtained on the solubility of the plutonium compound(s) (presumably sodium salts) formed by oxidation of excess Pu(IV) hydrous oxide by strong oxidants such as persulfate, hypochlorite, and hypobromite (Shilov et al. 1996). Demonstration of the presence of Pu(VI) in the solid phase was shown by change in precipitate color from green (Pu[IV]) to brown (Pu[VI]) and by spectrophotometric analysis of the acid-dissolved solids. The IPC/RAS data are shown in "gure 6-5 and are compared with Pu(VI) solution concentration data reported by Delegard (1985) and by Karraker (1995).

The solubility-limited Pu(VI) solution concentration found in the IPC/RAS studies rises about a factor of 20 as $\mathrm{NaOH}$ concentration increases from 0.4 to $2 \mathrm{M}$. From 2 to $8 \mathrm{M} \mathrm{NaOH}$, the plutonium concentration rises another factor of two. The data from Delegard (1985) in the range 1 to $4 \mathrm{M} \mathrm{NaOH}$ generally follow the IPC/RAS results. The plutonium concentration data of Karraker (1995) are invariant in the $\mathrm{NaOH}$ range tested (2 to $10 \mathrm{M} \mathrm{NaOH}$ ) and are markedly lower than the IPC/RAS results. As explained by Karraker (1995), the invariance may be because insufficient plutonium was added; this would also explain the lower apparent solubility observed by Karraker. 
Figure 6-4. Solubility of $\mathrm{Pu}(\mathrm{V})$ Salts in $\mathrm{NaOH}$ Solutions.

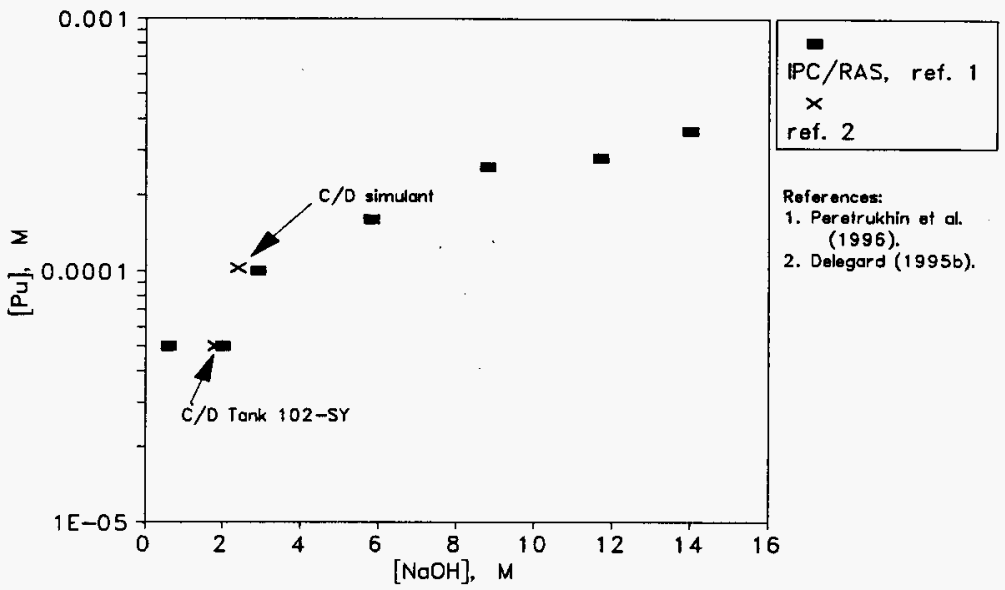

Figure 6-5. Solubility of Pu(VI) Salts in $\mathrm{NaOH}$ Solutions.

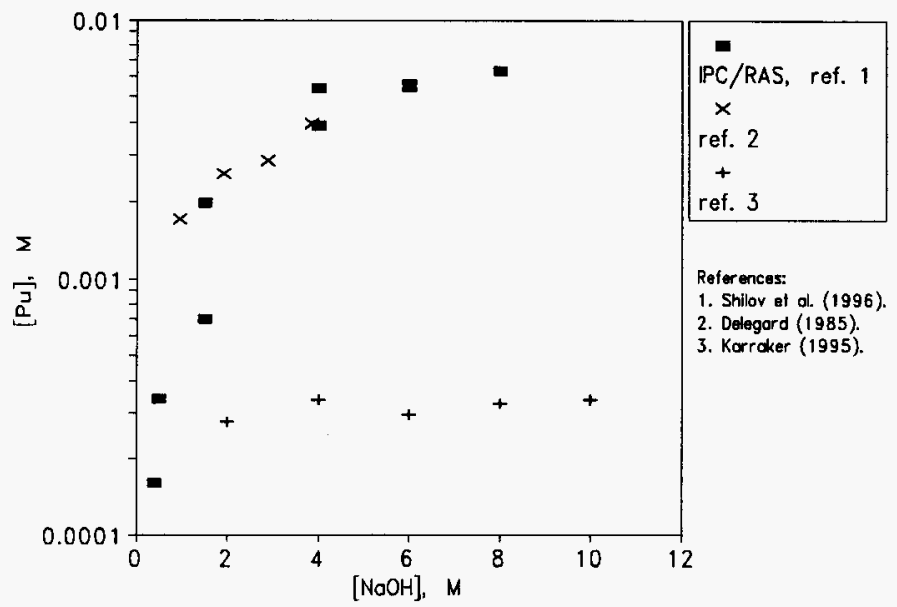




\subsubsection{Plutonium(IV) Carbonate}

The solubility enhancement to Pu(IV) hydrous oxide provided by 0.05 and $0.5 \mathrm{M} \mathrm{Na}_{2} \mathrm{CO}_{3}$ in 1 and $4 \mathrm{M} \mathrm{NaOH}$ solution was determined (Peretrukhin et al. 1996). The tests were conducted in the presence of $0.1 \mathrm{M}$ hydrazine holding reductant. The solubility of Pu(TV) hydrous oxide in carbonate solutions containing nitrite holding reductant was reported in the technical literature, and a $2: 1 \mathrm{CO}_{3}^{2-}: \mathrm{Pu}$ complex, postulated to be $\left[\mathrm{Pu}(\mathrm{OH})_{4}\left(\mathrm{CO}_{3}\right)_{2}\right]^{4}$, was proposed based on the apparent increase in solubility with an increase in carbonate concentration (Yamaguchi et al. 1994).

This interpretation was extended to results published by Delegard (1985) for solutions ranging from 3 to $5 \mathrm{M} \mathrm{NaOH}$ and containing 0.25 to $1 \mathrm{M} \mathrm{Na} \mathrm{CO}_{3}$. The two data sets were consistent and compatible with the postulated 2:1 carbonate:plutonium complex (Delegard 1995a). The IPC/RAS data are compared with these literature results in Figure 6-6. Plutonium concentration data from genuine Hanford Site tank waste solutions also are consistent and are plotted in Figure 6-6 (Bratzel 1985; and Herting 1994). The waste solutions contain relatively high carbonate concentrations $(0.3$ to $1.4 \mathrm{M})$ and low hydroxide concentrations (less than $0.9 \mathrm{M}$ ).

The enhancements in plutonium concentrations found by the IPC/RAS agree with those projected from the literature data at $0.5 \mathrm{M} \mathrm{Na}_{2} \mathrm{CO}_{3}$. However, the increases observed at $0.05 \mathrm{M} \mathrm{Na}_{2} \mathrm{CO}_{3}$ are higher than predicted and may be related to insufficient equilibration (contact) time or incomplete phase separation.

\subsubsection{Americium(III)}

The solubility of americium(III) hydroxide prepared by precipitation of Am(III) nitrate solution in 1.0 and $5.0 \mathrm{M} \mathrm{NaOH}$ was measured to be $(6.9$ and 6.0$) \times 10^{-6} \mathrm{M}$, respectively. The solubility of pre-formed $\mathrm{Am}(\mathrm{OH})_{3}$, aged by three hours' boiling water temperature, was (5.9 and 3.6) $\times 10^{-7} \mathrm{M}$, respectively. The contact time in both cases was 72 hours and phase separation was by centrifugation (Peretrukhin et al. 1996).

Published results generally confirm the IPC/RAS findings. In Weaver and Shoun (1971), the observed solubility-limited concentration in water for Am(III) hydroxide was $3.9 \times 10^{-6} \mathrm{M}$. These tests were conducted under argon cover gas, and the solubility was determined at about $\mathrm{pH}$ 8. The solid-liquid separation technique was not specified, and equilibration times were only minutes. In Pazukhin and Kochergin (1989), the solubility measured in aqueous solutions ranging from $\mathrm{pH} 8$ to $5 \mathrm{M} \mathrm{NaOH}$ was about $1.6 \times 10^{-6} \mathrm{M}$ and was practically independent of $\mathrm{pH}$, solid/solution ratio, and ionic strength. Equilibration times with the freshly-formed Am(III) hydroxide ranged from 0.5 to 1 hour, and centrifugation was used for phase separation. 
Figure 6-6. Enhancement of Plutonium Concentration Above Pu(IV) Hydrous Oxide Because of Carbonate Complexation in $\mathrm{NaOH} / \mathrm{Na}_{2} \mathrm{CO}_{3}$ Solutions.

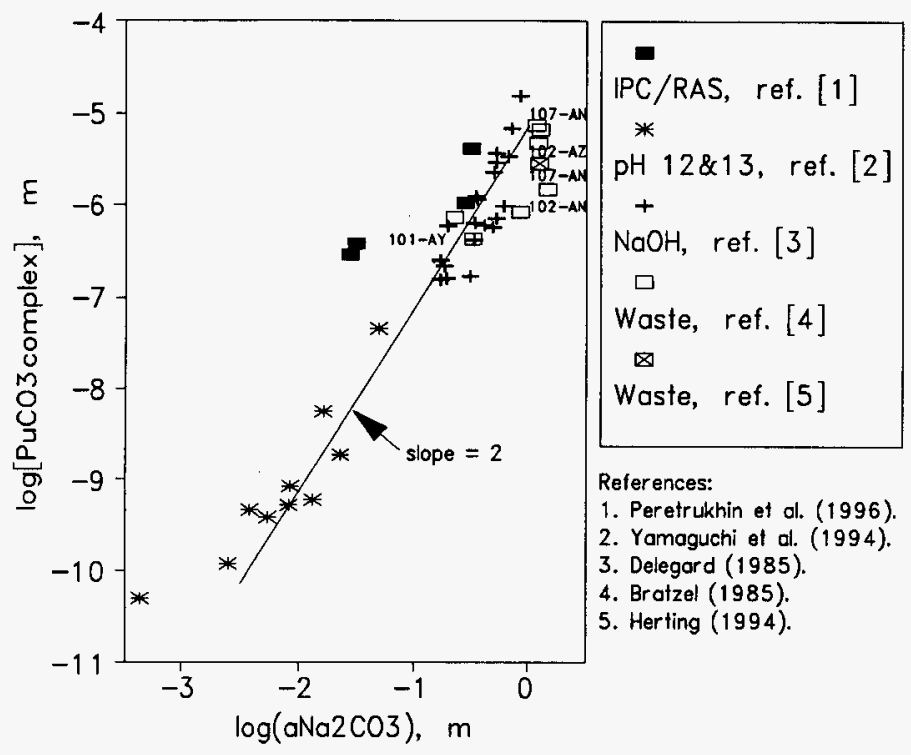

In contrast with these findings, however, americium concentrations in tests with aerated Hanford Site tank waste simulant solutions in the presence of low concentrations $\left(<10^{-5} \mathrm{M}\right)$ of organic complexants (EDTA, HEDTA, citrate, and hydroxyacetate) was about $2 \times 10^{-8} \mathrm{M}$; in the complete absence of organics, the Am concentrations were about $5 \times 10^{-9} \mathrm{M}$ (Delegard and Gallagher 1983). Contact time for these 1 to $4 \mathrm{M} \mathrm{NaOH}$ solutions was two weeks. The test solutions also contained nitrate, nitrite, carbonate, aluminate, fluoride, phosphate, and sulfate in varying concentrations. The oxidation state of americium was not identified or controlled in these tests. Americium(III) hydroxide solubility in solutions with $\mathrm{pH}$ between 10.5 and 13 were found to be invariant and about $10^{-10} \mathrm{M}$ (Rai et al. 1983). Both ${ }^{241} \mathrm{Am}$ and ${ }^{243} \mathrm{Am}$ were used in these tests, and experiments were conducted in controlled atmosphere gloveboxes from which carbon dioxide and oxygen were excluded. Steady-state concentrations were obtained in a few days. Ultrafiltration (pore size 3 and $1.8 \mathrm{~nm}$, respectively) was used to separate phases in the tests by Delegard and Gallagher (1983) and Rai et al. (1983).

The differences in these results are large and significant. The transuranic waste threshold is $100 \mathrm{nCi}$ long-lived alpha activity per gram of waste. For ${ }^{241} \mathrm{Am}$ solutions, that threshold is 
equivalent to $1.2 \times 10^{-7} \mathrm{M}$ and lies between the high solubility findings of Peretrukhin et al. (1996) and the lower concentrations found by Delegard and Gallagher (1983) and Rai et al. (1983).

The markedly higher concentrations in the tests by Peretrukhin et al. (1996) and Pazukhin and Kochergin (1989) may be because phases were separated only by centrifugation. Thus, the presence of stable colloids that do not settle by centrifugation may explain the higher observed solubilities in these studies. Equilibration times also may have been too short to permit crystallization of the $\mathrm{Am}(\mathrm{OH})_{3}$. Further tests by the IPC/RAS, using the supplied ultrafilters (which are identical with those used by Rai et al. 1983), may be useful to help resolve the differences.

\subsection{COPRECIPITATION}

The IPC/RAS investigated and reported using coprecipitation to remove neptunium and plutonium in their (V) and (VI) oxidation states from alkaline solutions. The bulk transition metal (hydr)oxide and sodium diuranate precipitants were prepared by homogeneous decomposition of alkali-soluble precursor compounds. The IPC/RAS scientists dubbed this process the "Method of Appearing Reagents" (Krot et al. 1996). The IPC/RAS work encompassed seven precipitants from eight soluble precursor complexes. Suitable comparisons of the coprecipitation behavior of neptunium and plutonium with manganese(IV) or (II) hydroxide were found in reported results of recent tests. The results of these coprecipitation tests with manganese are given in Table 6-1.

Table 6-1. Neptunium and Plutonium Decontamination Factors from Alkaline Solution and Genuine and Simulant Hanford Site Tank Waste.

\begin{tabular}{|c|c|c|c|}
\hline \multirow[b]{2}{*}{ Weinen } & \multicolumn{3}{|c|}{ 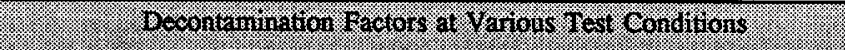 } \\
\hline & 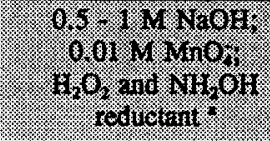 & 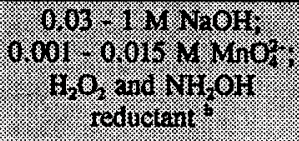 & 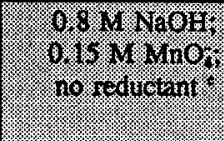 \\
\hline $\mathbf{N p}$ & 15 to 50 & 1 to 7 & -- \\
\hline Pu & 70 to 430 & 100 to 500 & 12 to 150 \\
\hline
\end{tabular}

Notes:

\footnotetext{
- Krot et al. (1996)

b Delegard (1995a)

- Orth et al. (1995).
} 
The tests performed by the IPC/RAS were with actinide-spiked $\mathrm{NaOH}$ solutions in which the added permanganate $\left(\mathrm{MnO}_{4}^{-}\right)$was caused to reduce and to precipitate as $\mathrm{MnO}_{2}$ and $\mathrm{Mn}(\mathrm{OH})_{2}$ with peroxide or hydroxylamine reductants, respectively. One comparison test used simulant and genuine Hanford Site tank wastes that had undergone calcination and dissolution treatment, then been treated with peroxide or hydroxylamine to reduce the manganate $\left(\mathrm{MnO}_{4}^{2-}\right)$ formed by calcination and dissolution processing to $\mathrm{Mn}(\mathrm{IV})$ precipitates (Delegard 1995a). The second comparison test involved genuine waste (from tank 241-SY-101) that had been treated with permanganate (Orth et al. 1995).

Solution DFs for plutonium were high, especially for the experiments using reductants. Neptunium DFs were much lower. In spite of the differences in the conditions under which the three studies were conducted, the experimental results were comparable.

In separate work, iron(II), (III), and (VI) precursor solutions have been tested to decontaminate simulated Hanford Site tank waste of neptunium, plutonium, and americium (Worl et al. 1995). Of these solutions, only the Fe(VI) precursor, which was tested only for Np(V), mirrored similar tests performed by the IPC/RAS (Krot et al. 1996). In both instances, neptunium coprecipitation was minimal.

\subsection{GAMMA RADIATION CHEMISTRY}

The IPC/RAS investigated the effects of gamma radiolysis on the stability of neptunium, plutonium, and technetium in alkaline solution (Pikaev et al. 1996). In particular, the stabilities of $10^{-4} \mathrm{M} \mathrm{Np}(\mathrm{VI}), \mathrm{Np}(\mathrm{V})$, and $\mathrm{Pu}(\mathrm{VI})$ in $\mathrm{NaOH}$ solutions under gamma irradiation were studied. Each actinide was chemically reduced by reactions in the bulk solution caused by gamma irradiation. The reduction yields were relatively insensitive to alkali concentration. For instance, the reduction yield of $\mathrm{Pu}(\mathrm{VI})$, irradiated to less than 1000 Grays $\left(10^{5} \mathrm{Rad}\right)$, was not changed by changing $\mathrm{NaOH}$ concentration in the range 1.3 to $6.9 \mathrm{M}$ $\mathrm{NaOH}$. However, the reductions were highly sensitive to the presence of organic materials in solution, with increased reduction yields even at trace organic concentrations.

The effects of the presence of nitrate $\left(\mathrm{NO}_{3}^{-}\right)$and nitrite $\left(\mathrm{NO}_{2}^{-}\right)$in the alkaline solutions also were investigated. With nitrate present, $\mathrm{Np}(\mathrm{VI})$ is reduced to $\mathrm{Np}(\mathrm{V})$, whereupon it reacts with radiolytically-produced peroxide and forms the $\mathrm{Np}(\mathrm{V})$ peroxide complex. The $\mathrm{Np}(\mathrm{V})$ peroxide complex was found to be unstable, however, if sufficient added nitrite also was present. Note that nitrite is created by extended radiolysis of nitrate. It was proposed by the IPC/RAS scientists that nitrite reacts with radiolytically-produced species (for example, $\mathrm{e}_{\mathrm{aq}}^{-}$ and $\mathrm{O}^{-}$) to form species (for example, $\mathrm{NO}_{2}^{2-}$ and $\mathrm{NO}_{2}$ ) which react to destroy radiolytically-produced peroxide. Complete reduction of $\mathrm{Np}(\mathrm{V})$ to $\mathrm{Np}(\mathrm{IV})$ did not occur if nitrate and/or nitrite were present. In contrast with the behavior of neptunium, plutonium(VI) was reduced to Pu(IV) even in the presence of nitrite. The analogous peroxide complex was not observed. 
Karraker (1995) examined the effect of gamma irradiation ( $5 \times 10^{4}$ Gray) on the stability of $\mathrm{Pu}(\mathrm{VI})$ hydroxide (as determined by reduction to $\mathrm{Pu}(\mathrm{IV})$ hydrous oxide) in solutions ranging from 2 to $10 \mathrm{M} \mathrm{NaOH}$. It was found that irradiation reduced $\mathrm{Pu}(\mathrm{VI})$ at lower hydroxide concentrations but had no effect at higher concentrations ( 8 to $10 \mathrm{M} \mathrm{NaOH})$. These findings are in contrast to those of Pikaev et al. (1996) who found Pu(VI) reduction yields by irradiation unaffected by $\mathrm{NaOH}$ concentration in the range of 1.3 to $6.9 \mathrm{M} \mathrm{NaOH}$.

Karraker (1995) determined the effect of $6 \times 10^{4}$ Gray irradiation on the Pu(VI)-spiked mixed $\mathrm{NaOH} / \mathrm{NaNO}_{3} / \mathrm{NaNO}_{2}$ solutions. Irradiation decreased plutonium concentrations for those experiments conducted at 1 or $2 \mathrm{M} \mathrm{NaOH}$ (nitrate and nitrite concentrations were 2 to $4 \mathrm{M}$ and 0.45 to $1.5 \mathrm{M}$, respectively). At $4 \mathrm{M} \mathrm{NaOH}$ (and $2.5 \mathrm{M}$ each nitrate and nitrite), plutonium concentration was increased somewhat above that observed in unirradiated control samples. These findings agree with the limited results presented by Pikaev et al. (1996).

Finally, Karraker (1995) examined the effect of initial plutonium valence on the products formed by gamma irradiation ( $\left.5 \times 10^{4} \mathrm{Gray}\right)$ in $\mathrm{NaOH}$ ranging from 2 to $10 \mathrm{M}$. Tests began with $\mathrm{Pu}(\mathrm{IV}), \mathrm{Pu}(\mathrm{VI})$, and mixed $\mathrm{Pu}(\mathrm{IV}) / \mathrm{Pu}(\mathrm{VI})$ tracers. After irradiation, the soluble plutonium in all experiments was present almost exclusively as Pu(VI). Control samples contained both $\mathrm{Pu}(\mathrm{IV})$ and $\mathrm{Pu}(\mathrm{VI})$ (with increasing $\mathrm{Pu}(\mathrm{VI})$ fraction as $\mathrm{NaOH}$ concentration increased) when $\mathrm{Pu}(\mathrm{IV})$ spike was used. For the control samples with the $\mathrm{Pu}$ (VI) spike and the mixed valence spike, the dissolved plutonium was hexavalent. Irradiation clearly decreased plutonium solubility at 2 to $6 \mathrm{M} \mathrm{NaOH}$ for all experiments containing $\mathrm{Pu}(\mathrm{VI})$ in the initial spike. These results are consistent with the findings of Pikaev et al. (1996). Plutonium solution concentrations in the irradiated solutions containing Pu(IV) spike were generally higher than the control samples. These results also agree with findings of an earlier study by Karraker (1994a).

In that earlier study, the effects of gamma irradiation on the solubility of Pu(IV) hydrous oxide in $\mathrm{NaOH}$ solutions in the presence and absence on nitrate and nitrite were examined (Karraker 1994a). In $\mathrm{NaOH}$ solutions without nitrate or nitrite, irradiation increased plutonium solution concentrations. The increase was greater as hydroxide concentration increased. With nitrate or nitrite present, particularly at higher concentrations, gamma irradiation had no discernible effect on plutonium solution concentration. 
WHC-SP-1186

This page intentionally left blank. 


\subsection{ACKNOWLEDGEMENTS}

The author is deeply indebted to Bette Lauzon, Rebecca Cooper, Judy Smart, Mary Curry, Penny Gregory, and Sylvia Harlow of Multimedia Services for their meticulous and professional work in editing and publishing the four IPC/RAS task reports (Krot et al. 1996; Peretrukhin et al. 1996; Pikaev 1996; and Shilov et al. 1996). 
WHC-SP-1186

This page intentionally left blank. 


\subsection{REFERENCES}

Bourges, J., 1972, "Preparation et Identification du Plutonium a l'Etat d'Oxydation-V en Milieu Basique," Radiochemical and Radioanalytical Letters, 12(2-3), pp. 111-119.

Bratsch, S. G., 1989, "Standard Electrode Potentials and Temperature Coefficients in Water at 298.15 K," Journal of Physical and Chemical Reference Data, 18(1), pp. 1-21.

Bratzel, D. R., 1985, "Characterization of Complexant Concentrate Supernatant," pp. 50-56, in Process Aids - A Compilation of Technical Letters, WHC-IP-0711, Volume 17, Westinghouse Hanford Company, Richland, Washington.

Delegard, C. H., and S. A. Gallagher, 1983, Effects of Hanford High-Level Waste Components on the Solubility of Cobalt, Strontium, Neptunium, Plutonium, and Americium, Rockwell Hanford Operations, Richland, Washington.

Delegard, C. H., 1985, Solubility of $\mathrm{PuO}_{2} \cdot \mathrm{xH}_{2} \mathrm{O}$ in Alkaline Hanford High-Level Waste Solution, RHO-RE-SA-75 P, Rockwell Hanford Operations, Richland, Washington. Also published in Radiochimica Acta 41, pp. 11-21.

Delegard, C. H., 1995a, Calcination/Dissolution Chemistry Development: FY 1995, WHC-EP-0882, Westinghouse Hanford Company, Richland, Washington.

Delegard, C. H., 1995b, Liaison Activities with the Institute of Physical Chemistry, Russian Academy of Science: FY 1995, WHC-SP-1166, Westinghouse Hanford Company, Richland, Washington.

Delegard, C. H., 1996, Calcination/Dissolution of Hanford Site Tank Waste, WHC-SA-2911-VA, Westinghouse Hanford Company, Richland, Washington.

Herting, D. L., 1994, "Characterization of Sludge Samples from Tank 241-AN-107," pp. 413-442, in Process Aids - A Compilation of Technical Letters by Process Laboratories and Technology, WHC-IP-0711-26, Westinghouse Hanford Company, Richland, Washington.

Herting, D. L., 1996, "Selective Crystallization of Tank Supernatant Liquid," pp. 109-111, in Efficient Separations and Processing Crosscutting Program 1996 Technical Exchange Meeting, PNNL-SA-27105, Pacific Northwest National Laboratory, Richland, Washington.

Karraker, D. G., 1994a, Radiation Effects on the Solubility of Plutonium in Alkaline High Level Waste, WSRC-MS-94-0278X (Rev. 2), Savannah River Technical Center, Aiken, South Carolina. 
Karraker, D. G., 1994b, Solubility of Neptunium in Alkaline High Level Waste, WSRC-TR-94-0526, Rev. 1, Savannah River Technical Center, Aiken, South Carolina.

Karraker, D. G., 1995, Plutonium(VI) Solubility Studies in Savannah River Site High-Level Waste Supernate, WSRC-TR-95-0244, Savannah River Technical Center, Aiken, South Carolina.

Krot, N., V. Shilov, A. Bessonov, N. Budantseva, I. Charushnikova, V. Perminov, and L. Astafurova, 1996, Investigation on the Coprecipitation of Transuranium Elements from Alkaline Solutions by the Method of Appearing Reagents, WHC-EP-0898, Westinghouse Hanford Company, Richland, Washington.

Maslennikov, A. G., V. F. Peretrukhin, and F. David, 1993, Proceedings of the Finnish Russian Symposium on Radiochemistry, S. Kulmala, editor, Helsinki, Finland, p. 12.

Orth, R. J., A. H. Zacher, A. J. Schmidt, M. R. Elmore, K. R. Elliott, G. G. Neuenschwander, and S. R. Gano, 1995, Removal of Strontium and Transuranics from Hanford Tank Waste via Addition of Metal Cations and Chemical Oxidant - FY 1995 Test Results, PNL-10766, Pacific Northwest Laboratory, Richland, Washington.

Pazukhin, É. M., and S. M. Kochergin, 1989, "Stability Constants of Hydrolyzed Forms of Americium(III) and Solubility Product of Its Hydroxide," Soviet Radiochemistry 31(4), pp. 430-436.

Peretroukhin, V. F., I. G. Tananaev, S. V. Kryutchkov, V. I. Silin, and C. H. Delegard, 1995, Solubility of Transuranium Elements and Technetium Hydroxide Compounds in $\mathrm{NaOH}$ Solutions in the Presence of Redox- and Complexing Agents, WHC-SA-2921-A, Westinghouse Hanford Company, Richland, Washington.

Peretrukhin, V. F., and D. P. Alekseeva, 1974, "Polarographic Properties of Higher Oxidation States of Plutonium in Aqueous Alkali Solutions," Soviet Radiochemistry 16(6), pp. 823-828.

Peretrukhin, V. F., F. David, and A. Maslennikov, 1994, "Electrochemical Properties and Thermodynamic Stability of Pu and Neighbouring Actinides in the (IV) and (V) Oxidation States in Aqueous Alkaline Media and Radwastes," Radiochimica Acta 65 , pp. 161-166.

Peretrukhin, V. F., V. P. Shilov, and A. K. Pikaev, 1995, Alkaline Chemistry of Transuranium Elements and Technetium and the Treatment of Alkaline Radioactive Wastes, WHC-EP-0817, Westinghouse Hanford Company, Richland, Washington. 
Peretrukhin, V. F., S. V. Kryutchkov, V. I. Silin, and I. G. Tananaev, 1996, Determination of the Solubility of $N p(I V)-(V I), P u(I I I)-(V I), A m(I I I)-(V I)$, and $T c(I V),(V)$ Hydroxo Compounds in 0.5 - $14 \mathrm{M} \mathrm{NaOH}$ Solutions, WHC-EP-0897, Westinghouse Hanford Company, Richland, Washington.

Peretrukhin, V. F., and V. I. Spitsyn, 1982, "Electrochemical Determination of the Oxidation Potentials and the Thermodynamic Stability of the Valence States of the Transuranium Elements in Aqueous Alkaline Media," Bulletin of the Academy of Sciences, Division of the Chemical Sciences, (4), pp. 726-730.

Pikaev, A. K., A. V. Gogolev, S. V. Kryutchkov, V. P. Shilov, V. N. Chulkov, L. I. Belyaeva, and L. N. Astafurova, 1996, Radiolysis of Actinides and Technetium in Alkaline Media, WHC-EP-0901, Westinghouse Hanford Company, Richland, Washington.

Rai, D., R. G. Strickert, D. A. Moore, and J. L. Ryan, 1983, "Am(III) Hydrolysis Constants and Solubility of Am(III) Hydroxide," Radiochimica Acta 33, pp. 201-206.

Shilov, V. P., N. N. Krot, N. Budantseva, A. Yusov, A. Garnov, V. Perminov, and L. Astafurova, 1996, Investigation of Some Redox Reactions of Neptunium, Plutonium, Americium, and Technetium in Alkaline Media, WHC-EP-0886, Westinghouse Hanford Company, Richland, Washington.

Tananaev, I. G., 1989, "Forms of Existence of Hexavalent Plutonium and Americium in Aqueous Alkaline Solutions," Soviet Radiochemistry 31(3), pp. 303-307.

Tananaev, I. G., 1990, "Forms of Neptunium(V) and Americium(V) in Basic Aqueous Media," Soviet Radiochemistry 32(5), pp. 476-479.

Tananaev, I. G., 1994, "Speciation of Np(V) in Solutions of Tetraalkylammonium Hydroxides," Radiochemistry 36(1), pp. 15-18.

Weaver, B., and R. R. Shoun, 1971, "Basicities of Trivalent Actinides and Lanthanides and Solubilities of Their Hydroxides," in Proceedings of the $g^{\text {h }}$ Rare Earth Research Conference, October 10 to 14, 1971, Blacksburg, Virginia, USAEC Report CONF-711001-(Vol. 1), p. 322. Also published in The Chemistry of Americium, W. W. Schulz, Energy Research and Development Administration, Technical Information Center, Oak Ridge, Tennessee, p. 149 (1976).

Worl, L. A., S. M. Bowen, J. M. Berg, D. D. Padilla, and M. R. Cisneros, 1995, Actinide Removal from Hanford Supernatant Tank Waste, LA-UR-95-3743, Los Alamos National Laboratory, Los Alamos, New Mexico. 
Yamaguchi, T., Y. Sakamoto, and T. Ohnuki, 1994, "Effect of the Complexation on Solubility of Pu(IV) in Aqueous Carbonate System," Radiochimica Acta 66/67, pp. 9-14. 


\section{DISTRIBUTION}

\section{Number of Copies}

\section{OFFSITE}

1

1

2

1
Thomas E, Albert and Associates, Inc. 34931 U. S. Highway 19 North, Suite 205

Palm Harbor, FL 34684

T. E. Albert

Oak Ridge National Laboratory

P. O. Box 2008

Oak Ridge, TN 37831-6178

J. S. Watson

Savannah River Technical Center

P. O. Box 616

Aiken, SC 29808

D. T. Hobbs

773-A

D. G. Karraker

773-H

U.S. Department of Energy

12800 Middlebrook Road

Trevion II Building

Germantown, MD 20874

K. Gerdes 
DISTRIBUTION (Continued)

Number of Copies

ONSITE

1

SAIC

D. J. Swanberg

Pacific Northwest National Laboratory

J. M. Gephart

W. L. Kuhn (2)

J. M. Tingey

4

U.S. Department of Energy

Richland Field Operations

R. F. Christensen

J. A. Frey

J. P. Hanson

B. A. Mauss
K8-50

H0-50

K2-21

K2-21

P7-25

K8-50

K8-50

K8-50

20

Westinghouse Hanford Company

J. D. Berger

H6-34

G. T. Berlin

H6-34

D. R. Bratzel

S7-14

C. H. Delegard (10)

G. B. Griffin

T6-09

D. L. Herting

T6-16

T6-09

J. R. Jewett

T6-09

B. G. Lauzon

R1-08

D. A. Reynolds

R2-11

DPC

A3-94

Central Files

A3-88 
WHC-SP-1186

\section{DISTRIBUTION (Continued)}

Number of Copies

ONSITE

1

SAIC

D. J. Swanberg

H0-50

4

Pacific Northwest National Laboratory

J. M. Gephart

K2-21

W. L. Kuhn (2)

K2-21

J. M. Tingey

P7-25

4

U.S. Department of Energy

Richland Field Operations

R. F. Christensen K8-50

J. A. Frey

K8-50

J. P. Hanson

K8-50

B. A. Mauss

K8-50

Westinghouse Hanford Company

J. D. Berger

H6-34

G. T. Berlin

H6-34

D. R. Bratzel

S7-14

C. H. Delegard (10)

T6-09

G. B. Griffin

T6-16

D. L. Herting

T6-09

J. R. Jewett

T6-09

B. G. Lauzon

R1-08

D. A. Reynolds

R2-11

DPC

A3-94

Central Files

A3-88

Distr-2 
THIS PAGE INTENTIONALLY

LEFT BLANK 